\title{
Effect of biogenic amine forming and degrading bacteria on quality characteristics of Kimchi
}

\author{
Eun-Seo Lim ${ }^{1}$
}

\section{바이오제닉 아민 생성균과 분해균이 김치의 품질 특성에 미치는 영향}

임 은 서 ${ }^{1}$

Received: 23 September 2020 / Accepted: 29 October 2020 / Published Online: 31 December 2020

(C) The Korean Society for Applied Biological Chemistry 2020

\begin{abstract}
The purpose of this study was to investigate the quality characteristics of kimchi prepared with a single starter culture of biogenic amines (BA)-forming lactic acid bacteria (LAB) or a combined starter cultures composed of BA-forming and BA-degrading LAB. As the fermentation proceeded, the lactic acid bacterial count, titratable acidity, and BA content in kimchi prepared with myeolchi-aekjeot were slightly higher than those of kimchi prepared with saeu-jeot. The amount and type of BA produced by $\mathrm{LAB}$ were mostly strain dependent rather than species specific. Among all of the isolated LAB strains, the highest levels of cadaverine, histamine, putrescine and tyramine were produced by Leuconostoc mesenteroides MBK32, Lactobacillus brevis MBK34, Lactobacillus curvatus MBK31 and Enterococcus faecalis SBK31, respectively. BA-forming and BAdegrading starter cultures played an important role in the growth rate and organic acid-producing ability of LAB in kimchi. Interestingly, BA contents in kimchi increased by adding single BA-forming LAB starter were effectively lowered by the mixed cultures with BA-degrading LAB.
\end{abstract}

Keywords Biogenic amine $\cdot$ Kimchi $\cdot$ Lactic acid bacteria

\section{Eun-Seo Lim $(\triangle)$}

E-mail: limsm020@tu.ac.kr

${ }^{1}$ Department of Food Science \& Nutrition, Tongmyong University, Busan 48520 , Republic of Korea

This is an Open Access article distributed under the terms of the Creative Commons Attribution Non-Commercial License (http://creativecommons. org/licenses/by-nc/3.0/) which permits unrestricted non-commercial use, distribution, and reproduction in any medium, provided the original work is properly cited.

\section{서 론}

식품의 저장성을 연장하기 위해 활용되는 건조, 저온 저장 및 통조림 등의 방법은 소량의 식품에 적용하기에는 경제적 효율 이 낮고 공정 중에 곰팡이, 저온성균이나 편성혐기성균 등 유 해 미생물의 증식 우려로 인해 안전성 문제 발생 위험이 높다 [1]. 이에 대한 대안에 될 수 있는 발효는 미생물의 다양한 효 소를 통해 생성된 대사 산물로 인하여 식품의 향이나 맛, 조직 감 등의 관능학적 품질 특성과 영양학적 가치를 향상시키므로 수 세기 동안 이용되어 온 역사적으로 가장 오래된 식품 보존 기술이다[2]. 발효는 냉장, 냉동, 통조림 및 기타 보존 방법에 비해 비교적 적은 에너지와 저렴한 비용으로 식품을 장기간 저 장할 수 있는 방법으로서 전 세계적으로 곡류, 유제품, 어류, 육 류, 과채류 및 두류 등 다양한 원료에 이용되고 있다[3]. 발효 미생물은 당을 분해하여 유기산, 이산화탄소, 알코올 및 항균물 질인 박테리오신 등을 생산함으로써 식품의 저장 기간을 연장 시키고 단백질이나 탄수화물의 소화율을 향상시키며 비타민이 나 무기질의 생체이용률을 증가시킨다[4]. 유산균, 초산균, 효모 및 곰팡이 등의 미생물로 발효된 식품은 혈중 콜레스테롤 수치 감소, 면역력 증강, 항균 및 항암 효과, 골다공증, 당뇨병, 비만, 알레르기, 죽상동맥경화증 및 유당불내증 완화 등 건강에 유익 한 작용을 하는 것으로 보고되고 있다[5].

하지만 전통 방식의 발효 식품은 위생적이지 못한 비 살균 환경 하에서 자연 발효를 통해 제조하게 되면 유해균의 오염으 로 인하여 진균독, 에틸카바메이트, 바이오제닉 아민(biogenic amines, BA) 등과 같이 미생물의 독소나 독성물질이 생성됨에 따라 중독 위험이 높아진다[6]. BA는 발효 스타터나 외부로부 터 오염된 미생물의 탈탄산 효소에 의해 아미노산이 분해되어 생성된 유해한 질소성 화합물로서 소량 함유된 식품을 섭취할 경우에는 체내 아민 산화효소(amine oxidase)에 의해 대사되어 무독화 된다[7]. 하지만 과도한 양의 $\mathrm{BA}$ 를 섭취하였거나 항고 
혈압이나 항우울제와 같은 산화효소 저해제에 의해 대사 시스 템이 손상된다면 히스타민, 티라민, 베타-페닐에틸아민 등과 같 은 혈관작용 $\mathrm{BA}$ 에 의해 식중독이 유발된다[8]. 게다가 푸트레 신, 카다베린, 스페르미딘 및 스페르민은 아질산과 반응하여 발 암물질인 N-니트로사민이 생성되고, 치즈반응(cheese reaction) 의 원인물질인 티라민은 고혈압, 두통, 뇌출혈 및 심근경색을 유발하게 되며, 고등어중독증(scombrotoxicosis)은 히스타민에 의 한 것으로 $500 \mathrm{mg} / \mathrm{kg}$ 이상을 섭취하면 메스꺼움, 두통, 호흡곤 란, 발진, 저혈압을 동반하게 된다[9]. BA가 과도하게 생성되면 비 위생적인 원료, 제조 환경과 공정 및 발효 과정 동안 외부 로부터 혼입된 아미노산 탈탄산 효소 생성 미생물에 기인하는 것으로 추정되므로 $\mathrm{BA}$ 는 식품의 취급 방식과 오염균의 존재 유무를 판단하는 지표로 이용된다[10].

$\mathrm{BA}$ 는 발효 육류, 어류, 유제품 및 와인이나 맥주 같은 발효 주 등에서 다량 검출될 뿐만 아니라 조직이 연하여 수확 후 쉽 게 변질되므로 저장성을 부여하기 위하여 발효시킨 채소류에서 도 $\mathrm{BA}$ 가 생성되는 것으로 보고되고 있다[10]. 과채류의 발효는 주로 우점종인 유산균에 의하며 이들은 주로 프로바이오틱 특 성을 나타내어 유익균으로 잘 알려져 있으나[11], 유산균의 일 부 균주들은 아미노산 탈탄산 효소를 생산함에 따라 김치나 사 우어크라우트 등에서도 히스타민, 카다베린, 푸트레신 등 다양 한 $\mathrm{BA}$ 가 검출된 바 있다[12,13]. 아미노산 탈탄산 효소는 세포 활성과는 무관하여 열악한 조건에서 세포가 용해 되어도 활성 은 유지되고 유산 발효에 의하여 $\mathrm{pH}$ 가 낮아진 환경에서 활성 이 최대에 이르므로 발효 식품에 의한 $\mathrm{BA}$ 중독 위험이 크다. 게다가 발효 기간이 길어질수록 $\mathrm{BA}$ 생성량이 증가되며 가열 처리, 냉동 및 훈연 조건에서도 $\mathrm{BA}$ 함량은 안정하게 유지되므 로 생으로 섭취하는 발효 채소류는 $\mathrm{BA}$ 독성에 대한 안전성 확 보에 어려움이 있다[14]. 따라서 이들에 대한 BA 생성을 억제 하기 위해 방법으로는 발효 식품 제조 원료와 환경으로부터 부 패 미생물의 오염을 최소화해야 하며 구성 성분의 아미노산 전 구체 함량을 감소시켜야 한다. 게다가 아미노산 탈탄산 효소 생 성능이 없는 스타터를 발효에 이용하거나 탈탄산 효소 분해능 이 있는 균주를 활용하는 방법도 보고되고 있다[15]. 선행 연구 결과[16], 묵은지로부터 분리된 유산균 Lactobacillus fermentum MML21 (카다베린 24.2 $\pm 0.9 \%$ ), Enterococcus faecium KML12 (히스타민 $41.7 \pm 2.2 \%$ 및 티라민 $25.3 \pm 0.4 \%$ ), Lactobacillus sakei MML23 (푸트레신 31.2 $\pm 4.8 \%$ 및 티라민 19.7 $\pm 4.1 \%$ ) 등 으로부터 $\mathrm{BA}$ 분해능이 확인된 바 있으며, 유산균이 생산한 박 테리오신은 BA 생성을 저해시키는데 효과적이었다.

본 연구에서는 우리나라 대표적인 발효 채소류인 김치 내의 $\mathrm{BA}$ 함량에 대한 액젓이나 젓갈의 종류 및 발효 기간의 영향을 살펴보고, $\mathrm{BA}$ 생성능이 있는 스타터로 제조한 김치 내 $\mathrm{BA}$ 함 량에 대한 $\mathrm{BA}$ 분해 유산균의 영향을 조사하였다.

\section{재료 및 방법}

\section{배추 김치 제조}

$\mathrm{BA}$ 분해균으로는 전보[16]의 묵은지로부터 분리된 Lactobacillus fermentum MML21, Enterococcus faecium KML12, Lactobacillus sakei MML23을 실험 균주로 사용하였다. BA 생성 유산균은
본 연구에서 사용된 김치에서 유래된 세균 중 4 종 $\mathrm{BA}$ 각각의 생성량이 가장 많은 균주를 이용하였다. $\mathrm{BA}$ 생성 및 분해 유 산균은 Lactobacilli MRS broth 상에서 $37^{\circ} \mathrm{C}$, overnight 배양 한 후 원심분리 $(7,000 \times \mathrm{g}, 20$ 분 $)$ 하여 세포만을 모았다. 인산완충 용액(phosphate buffer saline, PBS, pH 7.0)으로 2회 세척한 후 균수를 $1.0 \times 10^{7} \mathrm{CFU} / \mathrm{mL}$ 으로 조정하여 세포 현탁액을 준비 하였다.

전통 시장에서 구입한 배추는 다듬어서 반으로 자른 후 배추 $1 \mathrm{~kg}$ 당 $10 \%(\mathrm{w} / \mathrm{v})$ 천일염 용액에 담궈 상온에서 15 시간 침지 시켰다. 흐르는 수돗물로 3 회 씻은 다음 약 3시간 가량 방치하 여 물기를 제거하였다. 고춧가루 $(3.5 \%)$, 마늘 $(2.5 \%)$, 생강 $(0.5 \%)$, 양파 $(3.0 \%)$, 찹쌀풀 $(3.0 \%)$, 멸치 액젓 혹은 새우젓 $(2.5 \%)$ 을 혼 합한 다음 분쇄기(SMKANB-4000, PN, Korea)로 곱게 갈아서 만든 양념에 $\mathrm{BA}$ 생성균 현탁액 $(1.0 \%)$ 혹은 $\mathrm{BA}$ 생성균 및 분 해균 현탁액(각 $0.5 \%$ )을 접종한 후 절임 배추 $(84 \%)$ 에 골고루 묻혀 김치를 담궜다. 유산균을 접종하지 않은 대조구와 BA 생 성 유산균만 접종한 시료, $\mathrm{BA}$ 생성균과 분해균을 혼합 접종한 시료로 각각 구분하여 제조하였다. 담근 김치는 비닐백에 넣어 상온에서 하룻밤 정도 방치하여 숙성시킨 다음 $4{ }^{\circ} \mathrm{C}$ 와 $15^{\circ} \mathrm{C}$ 에 각각 저장하였다.

\section{BA 생성 유산균 분리 동정}

3 개월 발효된 김치 시료 $(50 \mathrm{~g})$ 에 9배의 $\mathrm{PBS}(\mathrm{pH}$ 7.0)를 가한 다음 스토마커(3 M, Maplewood, $\mathrm{MN}, \mathrm{USA})$ 로 3분간 균질화 하여 만든 시료 용액을 $1 \%(\mathrm{w} / \mathrm{v}) \mathrm{CaCO}_{3}$ 가 첨가된 Lactobacilli MRS agar (BD Difco Co., Sparks, $\mathrm{MD}, \mathrm{USA}$ ) 평판배지에 도말 접종하였다. $37^{\circ} \mathrm{C}$ 에서 48 시간 배양한 후 투명한 환을 생 성하는 집락을 채취하여 MRS agar (BD Difco Co.) 평판배지 상에서 3회 순수 분리 배양한 다음 Toy 등[17]의 방법을 일부 변형하여 카다베린, 히스타민, 푸트레신 및 티라민 생성능을 확 인하였다. 분리된 균주는 전구체 아미노산(L-histidine monohydrochloride monohydrate, L-tyrosine disodium slat, L-lysine monohydrochloride 및 L-ornithine monohydrochloride, Sigma-Aldrich, $1 \mathrm{~g} / \mathrm{L}$ ) 및 pyridoxial 5-phosphate $(1 \mathrm{mg} / \mathrm{L})$ 를 첨가한 decarboxylase broth에 접종하여 $37^{\circ} \mathrm{C}$ 에서 24 시간 배양을 5 회 실시하여 효소 유도를 촉진시켰다. 전구체 아미노산 $2 \%(\mathrm{w} / \mathrm{v})$ 가 첨가된 decarboxylase broth $(1 \mathrm{~mL})$ 에 전 배양액 $(0.5 \mathrm{~mL})$ 을 microtiter plate (BD Falcon, Franklin, Lakes, NJ, USA) well에 접종한 후 $37^{\circ} \mathrm{C}, 72$ 시간 동안 혐기적 조건(Anoxomat 8000 system, Mart B.V., Lichtenvoorde, The Netherlands)에서 배양한 다음 자색을 띠는 양성균을 선발하였다.

BA 생성능이 있는 유산균은 $\operatorname{Lim}$ [18]의 방법에 따라 DNA extraction kit (Qiagen, Hilden, Germany)를 사용하여 균주의 $\mathrm{DNA}$ 를 추출 정제한 후 27F (5'-AGAGTTTGATCCTGGCTCA G-3')와 1492R (5'-GGTTACCTTGTTACGACTT-3') primer를 사용하여 중합효소연쇄반응(polymerase chain reaction, PCR, Bio-Rad Laboratories Inc., Hercules, CA, USA) 으로 초기 변 성 $\left(94{ }^{\circ} \mathrm{C}, 3\right.$ 분 $)$, 변성 $\left(94{ }^{\circ} \mathrm{C}, 2\right.$ 분 $)$, 풀림 $\left(42{ }^{\circ} \mathrm{C}, 1\right.$ 분 $)$, 신장 $\left(72{ }^{\circ} \mathrm{C}\right.$, 2 분 $)$, 연장 $\left(72{ }^{\circ} \mathrm{C}, 7\right.$ 분 $)$ 순으로 36 회 반복시켜 $\mathrm{DNA}$ 를 증폭시켰 다. PCR 증폭 산물은 PCR purification kit (Qiagen)로 정제한 후 Dye Terminator Cycle Sequencing Ready Reaction Kit (Applied Biosystems, Foster City, CA, USA)와 ABI 3700 
sequencer (Biosystems)로 염기서열을 분석하였다. 염기서열의 상 동성은 National Center for Biotechnology Information (NCBI) 의 BLAST search program (http://www.ncbi.nlm.nih.gov)을 통 해 DNA 데이터베이스와 비교 분석하였다.

\section{분리 균주의 BA 생성량 측정}

분리 동정된 균주는 Lactobacilli MRS broth에 접종하여 $37^{\circ} \mathrm{C}$, 24 시간 동안 배양한 다음 전 배양액 $(0.1 \mathrm{~mL})$ 을 $\mathrm{BA}$ 생성용 합 성배지(1 L당 meat extract $8 \mathrm{~g}$, tryptone $5 \mathrm{~g}$, yeast extract $4 \mathrm{~g}$, glucose $1.5 \mathrm{~g}$, fructose $1 \mathrm{~g}$, Tween $800.5 \mathrm{~g}, \mathrm{MgSO}_{4} 0.2 \mathrm{~g}$, $\mathrm{FeSO}_{4} \quad 0.04 \mathrm{~g}, \mathrm{MnSO}_{4} 0.05 \mathrm{~g}, \mathrm{CaCO}_{3} 0.1 \mathrm{~g}$, tyrosine $2 \mathrm{~g}$, histidine $2 \mathrm{~g}$, ornithine $2 \mathrm{~g}$, lysine $2 \mathrm{~g}$, pyridoxal 5-phosphate $0.25 \mathrm{~g}, \mathrm{pH} 5.5$ )에 접종한 후 $28^{\circ} \mathrm{C}, 5$ 일간 배양하였다. 배양액 을 원심분리 $(7,000 \times \mathrm{g}, 10$ 분 $)$ 하여 얻은 상등액을 여과 제균한 다 음 $\mathrm{Han}$ 등[19]의 방법을 일부 변형하여 $\mathrm{BA}$ 함량을 측정하였다. 시료 $(5 \mathrm{~g})$ 에 $0.1 \mathrm{~N} \mathrm{HCl}(20 \mathrm{~mL})$ 을 가해 2분간 균질화 한 용액 을 원심분리 $(7,000 \times \mathrm{g}, 20$ 분)하여 상등액만을 회수하였다. 침전 물을 같은 방법으로 2회 반복 조작하여 모은 시료 용액(최종 $50 \mathrm{~mL})$ 을 여과 제균 $(0.45 \mu \mathrm{m}$ membrane filter, Millipore, Bedford, $\mathrm{MA}, \mathrm{USA}$ )하였다. 여기에 $\mathrm{BA}$ 혼합 표준 용액(cadaverine, histamine, putrescine, tyramine, $500 \mathrm{mg} / \mathrm{L}$ )과 $0.4 \mathrm{M}$ perchloric acid $(9 \mathrm{~mL}$, Merck, Kenilworth, NJ, USA)를 첨가하고 진탕 혼합한 다음 원심분리 $(3,000 \times \mathrm{g}, 10$ 분 $)$ 하였다. 상등액을 여과 (Whatman paper No. 1, Whatman, Maidstone, Kent, UK)하 여 모은 여액 $(1 \mathrm{~mL})$ 에 $2 \mathrm{~N}$ sodium hydroxide $(200 \mu \mathrm{L})$, sodium bicarbonate 포화 용액 $(300 \mu \mathrm{L})$ 및 아세톤에 용해시킨 dansyl chloride (Sigma-Aldrich, $10 \mathrm{mg} / \mathrm{mL}, 2 \mathrm{~mL}$ )를 첨가하여 $40{ }^{\circ} \mathrm{C}$ 에 서 약 45 분간 반응시켰다. $25 \%(\mathrm{v} / \mathrm{v})$ ammonium hydroxide $(100 \mu \mathrm{L})$ 를 첨가하여 잔존하는 dansyl chloride를 제거한 다음 상온에서 약 30 분간 방치하였다. Acetonitrile을 첨가한 시료 용 액(최종 $5 \mathrm{~mL})$ 은 원심분리 $(2,500 \times \mathrm{g}, 5$ 분)하여 상등액을 $0.22 \mu \mathrm{m}$ membrane filter (Millipore)로 여과하고 dansyl 유도체화 시킨 다음 high pressure liquid chromatography (HPLC, Shimadzu, Kyoto, Japan)로 시료 내 BA 함량을 측정하였다. Nova-Pak $\mathrm{C}_{18}$ 컬럼 $(150 \times 3.9 \mathrm{~mm}$, Waters, Milford, MA, USA) 온도는 $40{ }^{\circ} \mathrm{C}$, 이동상의 $\mathrm{A}, \mathrm{B}$ 용액은 각각 $0.1 \mathrm{M}$ ammonium acetate 와 acetonitrile을 사용하였고 시료 $(10 \mu \mathrm{L})$ 유속 $1 \mathrm{~mL} / \mathrm{min}$ 조건 하에서 분석하였다.

\section{유산균수 및 산도 측정}

시료 $(50 \mathrm{~g})$ 를 무균적으로 채취한 후 $\mathrm{PBS}(\mathrm{pH} 7.0,450 \mathrm{~mL})$ 을 가한 다음 약 2 분간 스토마커( $3 \mathrm{M}$, Maplewood, MN, USA)로 균질화 하였다. 시료 용액을 십진 희석하여 Lactobacilli MRS agar에 접종한 후 $37^{\circ} \mathrm{C}, 24-48$ 시간 동안 배양하여 유산균수를 측정하였다.

산도는 시료 $(10 \mathrm{~g})$ 에 동량의 증류수를 가한 후 $1 \%(\mathrm{w} / \mathrm{v})$ 페 놀프탈레인을 소량(3-4방울) 첨가한 다음 $0.1 \mathrm{~N} \mathrm{NaOH}$ 용액을 사용하여 적정 소비량을 계산식[산도 $(\%)=(0.1 \mathrm{~N} \mathrm{NaOH}$ 소비량 $\times 0.1 \mathrm{~N} \mathrm{NaOH}$ 역가 $\times 0.9$ )/시료량]에 대입하여 측정하였다.

\section{아미노산 함량 측정}

김치 시료의 $\mathrm{BA}$ 생성에 필요한 전구체 아미노산 함량 변화는
Lee 등[20]의 방법에 따라 측정하였다. 즉, 시료 $(50 \mathrm{~g})$ 에 $75 \%$ 에탄올 $250 \mathrm{~mL}$ 를 가하여 균질화 한 후 $75{ }^{\circ} \mathrm{C}, 60$ 분간 환류 추 출하여 얻은 잔사에 동일한 방법으로 2 회 반복 추출하였다. 추 출물을 $40{ }^{\circ} \mathrm{C}$ 에서 감압 농축한 다음 $0.2 \mathrm{M}$ citrate buffer로 용 해시켜 $50 \mathrm{~mL}$ 로 정용하고 syringer filter $(0.22 \mu \mathrm{m})$ 로 여과한 여액은 아미노산 자동분석기(Hitachi L-8800, Tokyo, Japan)로 분석하였다. Ultrapac 양이온 교환 수지 $(250 \mathrm{~mm})$ 를 이용하여 $\mathrm{pH}$ 별 $(2.80,3.00,3.15,3.50,3.55)$ citrate buffer 용액과 닌히 드린 유속은 $20 \mathrm{~mL} / \mathrm{h}$, 컬럼 온도는 $35-80^{\circ} \mathrm{C}$, 시료 주입량은 $20 \mu \mathrm{L}$, 차트 속도는 $2 \mathrm{~mm} / \mathrm{min}$ 의 조건에서 분석하였다.

\section{통계처리}

실험 항목별 측정은 3 회 반복하였고 결과값은 평균 \pm 표준편차 로 표시하였다. SPSS (Statistical Package Social Science, ver. 18.0, SPSS Inc., Chicago, IL, USA) 프로그램을 사용하여 실 험 결과를 통계 처리하였다. 측정값의 유의적인 차이는 일원분 산분석(one-way ANOVA)을 이용하여 $p<0.05$ 수준에서 Duncan's multiple range test로 검증하였다.

\section{결과 및 고찰}

\section{BA 생성균 분리 동정}

3개월간 발효 시킨 멸치 액젓과 새우젓으로 담근 김치 시료로 부터 $\mathrm{BA}$ 생성 유산균을 분리 동정한 결과는 Table 1과 같다. 멸치 액젓으로 담근 김치 시료로부터 Lactobacillus brevis MBK11, Lactobacillus plantarum MBK12, Weissella cibaria MBK13, Enterococcus faecalis MBK21, Pediococcus sp. MBK22, Weissella koreensis MBK23, Lactobacillus curvatus MBK31, Leuconostoc mesenteroides MBK32, L. sakei MBK33, L. brevis $\mathrm{MBK} 34$ 등이 검출되었다. 새우젓으로 담근 발효 김 치에서는 멸치 액젓 김치에 비해 $\mathrm{BA}$ 생성 유산균의 균주 수가 적었고 L. plantarum SBK11, Weissella confusa SBK21, L. sakei SBK22, E. faecalis SBK31, Leu. mesenteroides SBK32 등이 분리되었으며 김치 발효에 주요 우점종인 특정 유산균이 $\mathrm{BA}$ 를 생성하는 것으로 확인되었다. 새우젓 보다는 멸치 액젓으 로 담근 김치에서 $\mathrm{BA}$ 생성 유산균이 더 많이 검출되었는데 이 는 멸치 액젓 자체에 더 많은 $\mathrm{BA}$ 생성 유산균이 존재하였으므 로 이들을 첨가한 김치로부터 유래된 것으로 추정된다.

김치 발효에 관여하는 미생물은 원료, 염도 및 발효 조건에 따라 종류와 분포 양상이 크게 다르며, 유산균에 의한 유산 발 효를 통해 만들어진 발효 채소류이기는 하지만 호기성균, 효모 및 곰팡이 등 다양한 미생물이 존재한다. 유산균에 의해 당이 분해되어 유기산의 생성에 따라 $\mathrm{pH}$ 가 낮아짐으로써 김치의 저 장기간 동안 채소의 신선함을 유지할 수 있게 된다[21]. 김치 내 우점종 미생물로는 Leuconostoc sp., Weissella sp., Lactobacillus sp., Leuconostoc sp., Pediococcus sp.들이 있으며[22], 균종으 로는 Leu. mesenteroides, Leu. pseudomesenteroides, Lactococcus lactis, L. brevis 및 L. plantarum 등이 분리 동정되었고 이들은 김치의 발효에 중요한 역할을 하며 맛에도 영향을 미친다[23]. 김치로부터 가장 흔히 분리되는 Leuconostoc sp.에 속하는 종으 
Table 1 Identification of BA-forming LAB isolated from Baechu-kimchi prepared with Myeolchi-aekjeot and Saeu-jeot

\begin{tabular}{|c|c|c|c|c|c|}
\hline \multirow{2}{*}{ Source } & \multirow{2}{*}{ Sample No. } & \multirow{2}{*}{$\mathrm{LAB}$} & \multicolumn{3}{|c|}{ 16S rRNA sequencing } \\
\hline & & & Related strain in NCBI & GenBank Accession No. & BLAST similarity $(\%)$ \\
\hline \multirow{10}{*}{$\begin{array}{l}\text { Baechu-kimchi prepared } \\
\text { with Myeolchi-aekjeot }\end{array}$} & \multirow{3}{*}{1} & MBK11 & Lactobacillus brevis S2-9 & MN826743 & 99.2 \\
\hline & & MBK12 & Lactobacillus plantarum S107 & KT275942 & 98.7 \\
\hline & & MBK13 & Weissella cibaria KKMB4 & KX812809 & 99.0 \\
\hline & \multirow{3}{*}{2} & MBK21 & Enterococcus faecalis YN771 & MH919370 & 98.5 \\
\hline & & MBK22 & Pediococcus sp. P15 & MN120790 & 99.0 \\
\hline & & MBK23 & Weissella koreensis FK121 & KJ841932 & 99.9 \\
\hline & \multirow{4}{*}{3} & MBK31 & Lactobacillus curvatus B-1 & MH194554 & 98.9 \\
\hline & & MBK32 & Leuconostoc mesenteroides L25 & MN904837 & 99.0 \\
\hline & & MBK33 & Lactobacillus sakei L3 & MK640920 & 99.4 \\
\hline & & MBK34 & Lactobacillus brevis $\mathrm{Cn} 3$ & MN826735 & 99.5 \\
\hline \multirow{5}{*}{$\begin{array}{c}\text { Baechu-kimchi prepared } \\
\text { with Saeu-jeot }\end{array}$} & 1 & SBK11 & Lactobacillus plantarum S89 & KR025405 & 100.0 \\
\hline & \multirow{2}{*}{2} & SBK21 & Weissella confusa CT-37 & MH558379 & 99.0 \\
\hline & & SBK22 & Lactobacillus sakei YY1 & KM267631 & 100.0 \\
\hline & \multirow{2}{*}{3} & SBK31 & Enterococcus faecalis L2A21M3 & KM201352 & 100.0 \\
\hline & & SBK32 & Leuconostoc mesenteroides SG-051 & MG669293 & 99.9 \\
\hline
\end{tabular}

로는 Leu. mesenteroides, Leu. citreum, Leu. carnosum, Leu. gasicomitatum, Leu. inhae, Leu. gelidum, Leu. kimchi 및 Leu. miyukkimchii 등과 Lactobacillus sp.에 속하는 $L$. plantarum, L. brevis 및 L. sakei 등이 차지하고 있다[24]. Hong 등[25]도 김치 우점종 유산균으로 Pediococcus pentosaceus, Leu. citreum, Leu. gelidum, 및 Leu. mesenteroides 등을 분리 동정하였고, 이들 외에 Cheigh과 Park [26]는 Leu. dextranicum, Leu. citreum, L. fermentum, L. plantarum, $W$. koreensis, Weissella kimchi, Weissella pramsenteroides 등이 김치로부터 분리된 유산균이라고 보고하였다. Patra 등[27]에 따르면 Leu. carnosum, Leu. mesenteroides, Leu. gelidum, L. lactis, W. confusa, L. plantarum 및 L. sakei 등은 김치 시료에서 안정적 으로 검출되는 반면, Leu. citreum, Leu. gasicomitatum, Leu. kimchi, $W$. koreensis, $W$. cibaria, Lactobacillus spicheri, Lactobacillus parabrevis, L. brevis 및 L. curvatus 등은 산발 적으로 발생되며 유산균의 종류와 수는 발효 온도에 따라 상이 하다고 설명하였다. 특히 젓갈을 첨가하지 않은 김치에서는 $\mathrm{Leu}$. gasicomitatum, 새우 젓갈과 멸치 젓갈을 첨가한 김치에서는 $W$. koreensis와 L. sakei 등이 우점종으로 나타났다고 하여[28] 김 치에 첨가된 젓갈의 종류에 따라 분리된 유산균종이 다르다고 설명하였다. 본 연구의 결과에서 분리된 유산균은 이미 보고된 많은 연구 결과에서 밝힌 유산균종들과 부분적으로 일치하였다.

\section{분리된 유산균의 $\mathrm{BA}$ 생성능}

김치 시료로부터 분리된 유산균의 in vitro 상에서 $\mathrm{BA}$ 생성량 을 측정한 결과는 Table 2와 같다. Pediococcus sp. MBK22 $(158.2 \pm 22.3 \mathrm{mg} / \mathrm{L}), \quad$ Leu. mesenteroides MBK32 (241.4 \pm 30.1 $\mathrm{mg} / \mathrm{L})$ 및 L. sakei SBK22 $(99.5 \pm 2.4 \mathrm{mg} / \mathrm{L})$ 는 카다베린 생성균

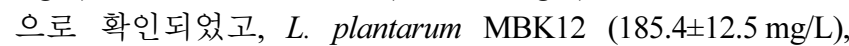
W. cibaria MBK13 $(160.4 \pm 17.1 \mathrm{mg} / \mathrm{L})$, W. koreensis MBK23 $(52.0 \pm 6.4 \mathrm{mg} / \mathrm{L})$, L. brevis MBK34 $(266.5 \pm 11.1 \mathrm{mg} / \mathrm{L}), W$. confusa
SBK21 (81.4 $\pm 13.6 \mathrm{mg} / \mathrm{L})$, E. faecalis SBK31 (131.5 $\pm 8.0 \mathrm{mg} /$ L) 및 Leu. mesenteroides SBK32 $(66.3 \pm 9.2 \mathrm{mg} / \mathrm{L})$ 등은 히스 타민을 생성하였다. 게다가 L. brevis MBK11 $(98.5 \pm 10.3 \mathrm{mg}$ / $\mathrm{L})$, E. faecalis MBK21 (55.6 $\pm 8.6 \mathrm{mg} / \mathrm{L})$, L. curvatus MBK31 $(147.8 \pm 5.0 \mathrm{mg} / \mathrm{L})$ 및 L. plantarum SBK11 $(67.2 \pm 1.3 \mathrm{mg} / \mathrm{L})$ 등 은 푸트레신을 생산하였고, E. faecalis MBK21 (46.9 $\pm 0.9 \mathrm{mg}$ ) L), L. curvatus MBK31 (33.9 $\pm 4.7 \mathrm{mg} / \mathrm{L})$, L. sakei MBK33 $(52.1 \pm 5.5 \mathrm{mg} / \mathrm{L})$, E. faecalis SBK31 $(129.1 \pm 20.1 \mathrm{mg} / \mathrm{L})$ 및 $\mathrm{Leu}$. mesenteroides SBK32 $(49.0 \pm 10.8 \mathrm{mg} / \mathrm{L})$ 등은 티라민을 생성하 였다. 따라서 유산균종보다는 균주에 따라 생산하는 $\mathrm{BA}$ 종류 가 다르고 $\mathrm{BA}$ 생성량에도 유의한 차이가 있었는데 $(p<0.05)$ 이 는 균주마다 이용 가능한 아미노산의 종류가 다르고 탈탄산 효 소의 활성에 따라 $\mathrm{BA}$ 생성량이 상이한 것으로 추정된다.

김치를 비롯한 많은 발효 식품의 우점종인 유산균은 역사적 으로 오랜 기간 사용되고 있음에 따라 GRAS (Generally Regarded As Safe) 균주로서 인체에 무해한 안전성이 입증되었고 면역 기 능 강화 및 항암 효과 등 다양한 생리활성을 발휘하는 것으로 알려져 있다[29,30]. 하지만 Lactobacilli, Enterococci, Lactococci, Pediococci, Streptococci 및 Leuconostoc 등 다양한 유산균들의 일부 균주들은 단백질 분해 산물인 유리 아미노산의 탈탄산화 를 통해 독성물질인 푸트레신, 카다베린, 히스타민 및 티라민을 생산하는 것으로 보고된 바 있다[31]. 특히 유산균은 당을 분해 하여 생성한 유산에 의해 $\mathrm{pH}$ 가 낮아진 환경에서 산에 대한 스 트레스를 중화시키는 능력 덕분에 아미노산 탈탄산화 시스템을 발현하여 최대의 효소 활성을 나타내므로 유산 발효 식품 내 $\mathrm{BA}$ 함량은 위험 수준에 이를 수 있다[14].

Barbieri 등[14]이 보고한 L. brevis (히스타민, 티라민, 베타페닐에틸아민, 카다베린, 푸트레신), L. plantarum (히스타민, 티 라민, 푸트레신), W. cibaria (히스타민, 티라민), E. faecalis (히 스타민, 티라민, 베타-페닐에틸아민, 카다베린, 푸트레신), Pediococcus sp. (카다베린), L. curvatus (티라민, 푸트레신), 
Table 2 BA-forming ability of LAB isolated from Baechu-kimchi prepared with Myeolchi-aekjeot and Saeu-jeot

\begin{tabular}{|c|c|c|c|c|c|}
\hline \multirow{2}{*}{ Source } & \multirow{2}{*}{ Strain } & \multicolumn{4}{|c|}{ BA-forming ability (mg/L) } \\
\hline & & Cadaverine & Histamine & Putrescine & Tyramine \\
\hline \multirow{10}{*}{$\begin{array}{c}\text { Baechu-kimchi prepared } \\
\text { with Myeolchi-aekjeot }\end{array}$} & Lactobacillus brevis MBK11 & ND & ND & $98.5 \pm 10.3^{\mathrm{C}}$ & ND \\
\hline & Lactobacillus plantarum MBK12 & ND & $185.4 \pm 12.5^{\mathrm{F}}$ & ND & ND \\
\hline & Weissella cibaria MBK13 & ND & $160.4 \pm 17.1^{\mathrm{E}}$ & ND & ND \\
\hline & Enterococcus faecalis MBK21 & ND & ND & $55.6 \pm 8.6^{\mathrm{A}}$ & $46.9 \pm 0.9^{\mathrm{B}}$ \\
\hline & Pediococcus sp. MBK22 & $158.2 \pm 22.3^{\mathrm{B}}$ & ND & ND & ND \\
\hline & Weissella koreensis MBK23 & ND & $52.0 \pm 6.4^{\mathrm{A}}$ & ND & ND \\
\hline & Lactobacillus curvatus MBK31 & ND & ND & $147.8 \pm 5.0^{\mathrm{D}}$ & $33.9 \pm 4.7^{\mathrm{A}}$ \\
\hline & Leuconostoc mesenteroides MBK32 & $241.4 \pm 30.1^{\mathrm{C}}$ & ND & ND & ND \\
\hline & Lactobacillus sakei MBK33 & ND & ND & ND & $52.1 \pm 5.5^{\mathrm{B}}$ \\
\hline & Lactobacillus brevis MBK34 & ND & $266.5 \pm 11.1^{\mathrm{G}}$ & ND & ND \\
\hline \multirow{5}{*}{$\begin{array}{c}\text { Baechu-kimchi prepared } \\
\text { with Saeu-jeot }\end{array}$} & Lactobacillus plantarum SBK11 & ND & ND & $67.2 \pm 1.3^{\mathrm{B}}$ & ND \\
\hline & Weissella confusa SBK21 & ND & $81.4 \pm 13.6^{\mathrm{C}}$ & ND & ND \\
\hline & Lactobacillus sakei SBK22 & $99.5 \pm 2.4^{\mathrm{A}}$ & ND & ND & ND \\
\hline & Enterococcus faecalis SBK31 & ND & $131.5 \pm 8.0^{\mathrm{D}}$ & ND & $129.1 \pm 20.1^{\mathrm{C}}$ \\
\hline & Leuconostoc mesenteroides SBK32 & ND & $66.3 \pm 9.2^{\mathrm{AB}}$ & ND & $49.0 \pm 10.8^{\mathrm{B}}$ \\
\hline
\end{tabular}

All values are the mean $\pm \mathrm{SD}$ of the three replicates

$\mathrm{ND}$, not detected

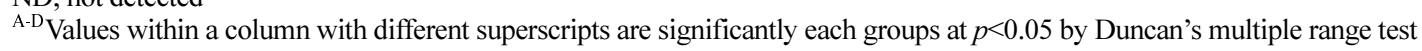

Leu. mesenteroides (히스타민, 티라민, 베타-페닐에틸아민, 카다 베린, 푸트레신), L. sakei (히스타민, 티라민, 푸트레신), W. confusa (히스타민, 티라민) 등은 본 연구에서 분리된 균주들과 일부 동일한 $\mathrm{BA}$ 를 생산하는 것으로 확인되었다. Lactobacillus paracasei subsp. paracasei, L. brevis, Brevibacillus brevis 등 은 각각 히스타민을 $15.1,13.6,16.3-43.1 \mu \mathrm{g} / \mathrm{mL}$ 생산하였고[32], 김치로부터 분리된 L. brevis, L. curvatus, Leu. mesenteroides 및 Staphylococcus aureus는 $200 \mu \mathrm{g} / \mathrm{mL}$ 이상의 티라민을 생성 하는 것으로 확인되었다[33]. 게다가 김치로부터 분리된 $L$. citreum, L. lactis, Leu. mesenteroides, W. cibaria, W. confusa 및 W. paramesenteroides가 푸트레신, 카다베린, 히스타민 및 티 라민 생성균으로 확인되어[34] 본 연구의 분리 유산균들도 이 들과 부분적으로 동일한 $\mathrm{BA}$ 를 생성하였다.

Park 등[12]은 배추 김치로부터 분리된 L. paracasei subsp. paracasei는 카다베린 $(0.3 \mu \mathrm{g} / \mathrm{mL})$, 히스타민 $(15.1 \mu \mathrm{g} / \mathrm{mL})$ 을 생산 한 반면 푸트레신과 티라민을 생산하지 않았다. L. brevis는 푸 트레신 $(0.2 \mu \mathrm{g} / \mathrm{mL})$, 카다베린 $(0.8 \mu \mathrm{g} / \mathrm{mL})$, 히스타민 $(13.6 \mu \mathrm{g} / \mathrm{mL})$ 을 생산한 반면 티라민을 생산하지 않았으나, 또 다른 시료에 서부터 분리된 L. brevis, L. curvatus와 Leu. mesenteroides는 이들 BA를 생산하지 않았다. Leu. citreum (카다베린 18.1-18.2 $\mu \mathrm{g} / \mathrm{mL}$ ), L. lactis (푸트레신 15.6-16.2 $\mu \mathrm{g} / \mathrm{mL}$ ), Leu. mesenteroides (카다베린 17.6-19.1 $\mu \mathrm{g} / \mathrm{mL}$ ), W. cibaria (푸트레신 불검출-17.7 $\mu \mathrm{g} / \mathrm{mL}$, 카다베린 불검출- $18.8 \mu \mathrm{g} / \mathrm{mL}$, 히스타민 불검출- $72.9 \mu \mathrm{g}$ / $\mathrm{mL}$, 티라민 불검출-59.9 $\mu \mathrm{g} / \mathrm{mL}$ ), W. confusa (푸트레신 불검출$17.1 \mu \mathrm{g} / \mathrm{mL}$, 카다베린 불검출- $19.5 \mu \mathrm{g} / \mathrm{mL}$, 히스타민 불검출- 73.3 $\mu \mathrm{g} / \mathrm{mL}$, 티라민 불검출-56.6 $\mu \mathrm{g} / \mathrm{mL}$ ), W. paramesenteroides (히 스타민 $55.2 \mu \mathrm{g} / \mathrm{mL}$, 티라민 $56.3 \mu \mathrm{g} / \mathrm{mL}$ ) 등으로부터 $\mathrm{BA}$ 생성 능이 확인된 바 있으며 본 연구 결과와 동일한 균종일지라도 생성량에 차이가 있었다.
김치에서 분리된 유산균의 균주에 따라 $\mathrm{BA}$ 종류 및 함량이 상이한 것으로 알려져 있으며 $\mathrm{BA}$ 생산량은 원료나 생산 환경 으로부터 유래된 아미노산 탈탄산 효소를 생산하는 미생물의 전 구체 아미노산 이용능에 의존한다[12]. 유리 아미노산은 식품 내에 자연적으로 존재하거나, 원료 자체에 함유된 내재적 단백 질 분해 효소 및 미생물의 효소들에 의해 단백질이 가수분해되 면 아미노산이 유리되어 탈탄산 효소 반응을 위한 기질로 제공 된다. 미생물의 탈탄산 효소 활성은 세포의 활성과는 무관하게 열악한 환경 하에서 세포가 용해된 후에도 계속해서 유지되어 가열 처리, 냉동이나 훈연 처리 조건 하에서도 안정하게 유지 되는 것으로 밝혀졌다[14]. 비록 발효 스타터가 탈탄산 효소 활 성이 없는 균주로 사용되었다고 할지라도 발효와 관련된 토착 유산균에 의해 $\mathrm{BA}$ 가 축적될 수 있다. 비 스타터 유산균인 중 온성 통성혐기성 혹은 편성 이상발효균들은 향미 생성을 비롯 하여 숙성 현상에 중요한 역할을 한다. 이들은 열악한 성장 조 건 하에 높은 적응력과 아미노산과 같은 기질로부터 성장과 에 너지 획득 능력이 있으므로 당의 고갈 후에도 오랜 기간 동안 생존할 수 있다[35]. 또한 낮은 $\mathrm{pH}$ 를 중화할 수 있는 항상성 메커니즘을 활성화하여 산성 조건 하에서 생존할 수 있고 아미 노산 탈탄산화 시스템의 전사적 유도 발현과 촉매적 조정에 의 한 활성은 산에 대한 스트레스를 중화시키고 에너지 고갈에 대 한 적응 반응이라고 보고된 바 있다[36].

\section{배추 김치 내 유산균수와 산도에 대한 발효 스타터의 영향}

$\mathrm{BA}$ 생성 유산균과 분해 유산균으로 제조한 김치를 $4{ }^{\circ} \mathrm{C}$ 및 $15^{\circ} \mathrm{C}$ 에서 각각 발효시키는 동안 유산균수 및 산도 변화를 측정 한 결과는 Table 3 및 4와 같다. 스타터를 첨가하지 않고 갓 담근 김치 내 유산균수는 $5.4 \pm 0.4 \times 10^{4} \mathrm{CFU} / \mathrm{g}$ 이었고, $4{ }^{\circ} \mathrm{C}$ 및 $15^{\circ} \mathrm{C}$ 에서 90 일간 발효 시킨 후 유산균수는 각각 $3.0 \pm 0.9 \times 10^{6}$ 
Table 3 Effect of biogenic amine (BA)-forming and degrading starter cultures on changes of LAB counts in Baechu-kimchi prepared with Myeolchi-aekjeot during fermentation

\begin{tabular}{|c|c|c|c|c|c|c|c|}
\hline \multirow{3}{*}{ Starter } & \multicolumn{7}{|c|}{ Viable cell counts $(\mathrm{CFU} / \mathrm{g})$} \\
\hline & \multirow{2}{*}{0} & \multicolumn{3}{|c|}{$4{ }^{\circ} \mathrm{C}$} & \multicolumn{3}{|c|}{$15^{\circ} \mathrm{C}$} \\
\hline & & 30 days & 60 days & 90 days & 30 days & 60 days & 90 days \\
\hline None & $5.4 \pm 0.4 \times 10^{4 \mathrm{aA}}$ & $2.7 \pm 1.9 \times 10^{5 \mathrm{bA}}$ & $7.0 \pm 2.1 \times 10^{5 \mathrm{cA}}$ & $3.0 \pm 0.9 \times 10^{6 \mathrm{dA}}$ & $1.8 \pm 2.6 \times 10^{6 \mathrm{cdA}}$ & $9.1 \pm 2.4 \times 10^{6 \mathrm{eA}}$ & $4.1 \pm 0.8 \times 10^{7 \mathrm{fA}}$ \\
\hline Leuconostoc mesenteroides MBK32 & $1.4 \pm 0.3 \times 10^{7 \mathrm{aB}}$ & $5.0 \pm 1.6 \times 10^{7 \mathrm{bB}}$ & $3.6 \pm 0.7 \times 10^{8 \mathrm{eB}}$ & $9.0 \pm 2.0 \times 10^{7 \mathrm{bcB}}$ & $6.1 \pm 1.1 \times 10^{8 \mathrm{fBC}}$ & $2.4 \pm 0.8 \times 10^{9 \mathrm{gB}}$ & $7.1 \pm 3.0 \times 10^{8 \mathrm{fB}}$ \\
\hline Leuconostoc mesenteroides MBK32 Lactobacillus fermentum MML21 & $4.4 \pm 1.7 \times 10^{7 \mathrm{aB}}$ & $8.4 \pm 3.0 \times 10^{7 \mathrm{abB}}$ & $6.6 \pm 1.9 \times 10^{9 \mathrm{eC}}$ & $2.7 \pm 0.1 \times 10^{9 \mathrm{dD}}$ & $9.7 \pm 2.5 \times 10^{8 \mathrm{cBC}}$ & $3.9 \pm 4.0 \times 10^{9 \mathrm{cdB}}$ & $1.1 \pm 2.3 \times 10^{9 \mathrm{dBC}}$ \\
\hline Lactobacillus brevis MBK34 & $5.5 \pm 2.9 \times 10^{7 \mathrm{aB}}$ & $5.7 \pm 1.8 \times 10^{8 \mathrm{bB}}$ & $1.5 \pm 0.1 \times 10^{9 \mathrm{cdC}}$ & $4.8 \pm 2.7 \times 10^{9 \mathrm{eD}}$ & $3.9 \pm 1.7 \times 10^{9 \mathrm{eC}}$ & $6.9 \pm 1.9 \times 10^{9 \mathrm{eB}}$ & $9.3 \pm 1.5 \times 10^{8 \mathrm{cB}}$ \\
\hline Lactobacillus brevis MBK34 Enterococcus faecium KML12 & $3.7 \pm 1.5 \times 10^{7 \mathrm{aB}}$ & $4.0 \pm 3.2 \times 10^{8 \mathrm{bB}}$ & $8.9 \pm 0.6 \times 10^{8 \mathrm{cBC}}$ & $2.9 \pm 1.6 \times 10^{9 \mathrm{dD}}$ & $8.1 \pm 2.2 \times 10^{8 \mathrm{bcBC}}$ & $3.4 \pm 0.9 \times 10^{9 \mathrm{~dB}}$ & $5.5 \pm 1.8 \times 10^{9 \mathrm{deC}}$ \\
\hline Lactobacillus curvatus MBK31 & $6.3 \pm 2.0 \times 10^{7 \mathrm{aBC}}$ & $2.2 \pm 0.6 \times 10^{8 \mathrm{bB}}$ & $1.7 \pm 2.5 \times 10^{9 \mathrm{dC}}$ & $6.2 \pm 1.5 \times 10^{8 \mathrm{cC}}$ & $1.0 \pm 2.1 \times 10^{9 \mathrm{dC}}$ & $5.7 \pm 1.7 \times 10^{9 \mathrm{eB}}$ & $8.0 \pm 0.8 \times 10^{8 \mathrm{cB}}$ \\
\hline Lactobacillus curvatus MBK31 $\quad$ Lactobacillus sakei MML23 & $4.0 \pm 2.3 \times 10^{7 \mathrm{aB}}$ & $8.8 \pm 1.3 \times 10^{7 \mathrm{bB}}$ & $3.4 \pm 0.5 \times 10^{8 \mathrm{cB}}$ & $7.9 \pm 3.3 \times 10^{8 \mathrm{cdC}}$ & $1.1 \pm 0.9 \times 10^{8 \mathrm{bcB}}$ & $1.7 \pm 2.3 \times 10^{9 \mathrm{~dB}}$ & $4.9 \pm 0.8 \times 10^{8 \mathrm{cB}}$ \\
\hline Enterococcus faecalis SBK31 & $5.0 \pm 1.9 \times 10^{7 \mathrm{aB}}$ & $2.9 \pm 1.1 \times 10^{8 \mathrm{bB}}$ & $9.5 \pm 3.0 \times 10^{8 \mathrm{cdBC}}$ & $6.3 \pm 0.8 \times 10^{8 \mathrm{CC}}$ & $5.5 \pm 2.0 \times 10^{8 \mathrm{cB}}$ & $2.1 \pm 0.4 \times 10^{9 \mathrm{~dB}}$ & $1.8 \pm 2.6 \times 10^{9 \mathrm{dBC}}$ \\
\hline Enterococcus faecalis SBK31 Enterococcus faecium KML12 & $8.6 \pm 1.5 \times 10^{7 \mathrm{aBC}}$ & $5.9 \pm 2.6 \times 10^{8 \mathrm{bB}}$ & $1.4 \pm 0.4 \times 10^{9 \mathrm{cC}}$ & $9.9 \pm 3.6 \times 10^{7 \mathrm{aB}}$ & $8.3 \pm 1.1 \times 10^{8 \mathrm{bBC}}$ & $3.5 \pm 1.8 \times 10^{9 \mathrm{cB}}$ & $7.9 \pm 0.9 \times 10^{8 \mathrm{bB}}$ \\
\hline \multicolumn{8}{|c|}{$\begin{array}{l}\text { All values are the mean } \pm \mathrm{SD} \text { of the three replicates } \\
\text { a-g Values within a row with different superscripts are significantly each groups at } p<0.05 \text { by Duncan's multiple range test } \\
\text { A-D Values within a column with different superscripts are significantly each groups at } p<0.05 \text { by Duncan's multiple range test }\end{array}$} \\
\hline \multirow{3}{*}{ Starter } & \multirow{3}{*}{0} & \multicolumn{5}{|c|}{ Titrability $(\%)$} & \\
\hline & & & $4{ }^{\circ} \mathrm{C}$ & & & $15^{\circ} \mathrm{C}$ & \\
\hline & & 30 days & 60 days & 90 days & 30 days & 60 days & 90 days \\
\hline None & $0.22 \pm 0.02^{\mathrm{aA}}$ & $0.56 \pm 0.04^{\mathrm{bA}}$ & $0.99 \pm 0.05^{\mathrm{dA}}$ & $1.10 \pm 0.04^{\mathrm{eB}}$ & $0.79 \pm 0.00^{\mathrm{cA}}$ & $1.00 \pm 0.01^{\mathrm{dA}}$ & $1.25 \pm 0.02^{\mathrm{efAB}}$ \\
\hline Leuconostoc mesenteroides MBK32 & $0.30 \pm 0.05^{\mathrm{aB}}$ & $0.69 \pm 0.06^{\mathrm{bBC}}$ & $1.03 \pm 0.03^{\mathrm{dAB}}$ & $1.14 \pm 0.02^{\mathrm{eBC}}$ & $0.82 \pm 0.04^{\mathrm{cA}}$ & $1.16 \pm 0.03^{\mathrm{eBC}}$ & $1.30 \pm 0.02^{\mathrm{fB}}$ \\
\hline Leuconostoc mesenteroides MBK32 Lactobacillus fermentum MML21 & $0.33 \pm 0.03^{\mathrm{aBC}}$ & $0.81 \pm 0.06^{\mathrm{bC}}$ & $1.20 \pm 0.02^{\mathrm{dC}}$ & $1.23 \pm 0.04^{\mathrm{dC}}$ & $1.03 \pm 0.06^{\mathrm{cC}}$ & $1.30 \pm 0.04^{\mathrm{dC}}$ & $1.38 \pm 0.05^{\mathrm{eC}}$ \\
\hline Lactobacillus brevis MBK34 & $0.28 \pm 0.04^{\mathrm{aB}}$ & $0.77 \pm 0.01^{\mathrm{bC}}$ & $0.96 \pm 0.04^{\mathrm{cA}}$ & $1.01 \pm 0.01^{\mathrm{cA}}$ & $0.95 \pm 0.08^{\mathrm{cB}}$ & $1.08 \pm 0.06^{\mathrm{cdB}}$ & $1.29 \pm 0.04^{\mathrm{eB}}$ \\
\hline Lactobacillus brevis MBK34 Enterococcus faecium KML12 & $0.36 \pm 0.01^{\mathrm{aC}}$ & $0.86 \pm 0.03^{\mathrm{bCD}}$ & $1.04 \pm 0.066^{\mathrm{bAB}}$ & $1.10 \pm 0.06^{\mathrm{bB}}$ & $1.08 \pm 0.01^{\mathrm{bC}}$ & $1.20 \pm 0.01^{\mathrm{cBC}}$ & $1.33 \pm 0.03^{\mathrm{dBC}}$ \\
\hline Lactobacillus curvatus MBK31 & $0.29 \pm 0.02^{\mathrm{aB}}$ & $0.59 \pm 0.02^{\mathrm{bA}}$ & $0.88 \pm 0.00^{\mathrm{cA}}$ & $1.06 \pm 0.03^{\mathrm{dB}}$ & $0.76 \pm 0.05^{\mathrm{cA}}$ & $1.11 \pm 0.00^{\mathrm{dB}}$ & $1.24 \pm 0.03^{\mathrm{eAB}}$ \\
\hline Lactobacillus curvatus MBK31 $\quad$ Lactobacillus sakei MML23 & $0.31 \pm 0.05^{\mathrm{aBC}}$ & $0.68 \pm 0.05^{\mathrm{bB}}$ & $1.07 \pm 0.01^{\mathrm{dAB}}$ & $1.09 \pm 0.01^{\mathrm{dB}}$ & $0.94 \pm 0.02^{\mathrm{cB}}$ & $1.27 \pm 0.01^{\mathrm{eC}}$ & $1.30 \pm 0.02^{\mathrm{eBC}}$ \\
\hline Enterococcus faecalis SBK31 & $0.26 \pm 0.03^{\mathrm{aB}}$ & $0.64 \pm 0.01^{\mathrm{bB}}$ & $0.99 \pm 0.03^{\mathrm{dA}}$ & $1.15 \pm 0.01^{\mathrm{eBC}}$ & $0.82 \pm 0.02^{\mathrm{cA}}$ & $1.18 \pm 0.02^{\mathrm{eBC}}$ & $1.20 \pm 0.01^{\mathrm{eA}}$ \\
\hline Enterococcus faecalis SBK31 Enterococcus faecium KML12 & $0.27 \pm 0.04^{\mathrm{aB}}$ & $0.71 \pm 0.03^{\mathrm{bBC}}$ & $1.16 \pm 0.02^{\mathrm{dC}}$ & $1.19 \pm 0.02^{\mathrm{dBC}}$ & $0.96 \pm 0.01^{\mathrm{cB}}$ & $1.29 \pm 0.02^{\mathrm{eC}}$ & $1.33 \pm 0.02^{\mathrm{eBC}}$ \\
\hline \multicolumn{8}{|c|}{$\begin{array}{l}\text { All values are the mean } \pm \mathrm{SD} \text { of the three replicates } \\
\text { a-f Values within a row with different superscripts are significantly each groups at } p<0.05 \text { by Duncan's multiple range test } \\
\text { A-C Values within a column with different superscripts are significantly each groups at } p<0.05 \text { by Duncan's multiple range test }\end{array}$} \\
\hline
\end{tabular}


$\mathrm{CFU} / \mathrm{g}$ 와 $4.1 \pm 0.8 \times 10^{7} \mathrm{CFU} / \mathrm{g}$ 으로 측정되었다. $\mathrm{BA}$ 생성균 단독 으로 담근 직후의 김치 유산균수는 $1.4 \pm 0.3-6.3 \pm 2.0 \times 10^{7} \mathrm{CFU} / \mathrm{g}$ 로 측정되었고 $\mathrm{BA}$ 분해균과의 혼합 스타터로 제조한 김치에서 는 3.7 $\pm 1.5-8.6 \pm 1.5 \times 10^{7} \mathrm{CFU} / \mathrm{g}$ 로 나타났다. 모든 실험구의 균수 는 발효가 진행될수록 서서히 증가되었으며 $4{ }^{\circ} \mathrm{C}$ 보다 $15^{\circ} \mathrm{C}$ 에 서 유의하게 증가되었다 $(p<0.05)$. L. brevis MBK34 스타터에 의해선 초기 균수로부터 90 일만에 최대 $2 \mathrm{log}$ cycle 가량 증가 되었으나, Leu. mesenteroides MBK32, L. curvatus MBK31 및 E. faecalis $\mathrm{SBK} 31$ 스타터는 60 일 후에 균수가 감소되는 경향으로 나타났다. L. brevis MBK34와 E. faecium KML12의 혼합 스타터를 사용하여 $15^{\circ} \mathrm{C}$ 에서 90 일간 발효 시킨 김치에서 유산균수가 가장 높게 나타났다.

스타터를 사용하지 않은 담근 직후 김치의 산도는 $0.22 \pm 0.02 \%$ 이었으나 발효가 진행될수록 미생물 증식에 따른 유기산의 생 성으로 산도가 점진적으로 증가되었고 $4{ }^{\circ} \mathrm{C}$ 보다는 $15^{\circ} \mathrm{C}$ 에서 유의하게 높게 나타났다 $(p<0.05)$. 스타터를 사용한 담근 김치의 산도는 대조구와 비슷한 수준이었으나 시간이 경과됨에 따라 산 도는 스타터 첨가구에서 더 높게 측정되었다. 게다가 $\mathrm{BA}$ 생성 균 단독 스타터 보다는 $\mathrm{BA}$ 분해균과의 혼합 스타터로 제조한 김치에서 더 높은 산도가 측정되었다.

Leu. mesenteroides MBK32와 L. fermentum MML21의 혼 합 스타터를 사용하여 $15^{\circ} \mathrm{C}$ 에서 90 일간 발효 시킨 김치에서 산도가 가장 높게 나타났다. 이상의 결과 김치에 스타터를 접 종함으로써 초기 균수는 대조구에 비해 유의하게 높았고 $(p<0.05)$ 발효 온도가 높을수록 유산균의 증식 속도는 빠르고 이에 따라 유기산의 생성량도 증가되어 산도는 균수에 비례적으로 증가되 었다. 동일한 조건 하에서 발효시키는 동안 사용된 스타터 균 주에 따라 균수와 산도에 차이가 나는 것은 영양분 이용능이나 발효 환경에 대한 적응 능력에 따른 것으로 추정된다. 또한 $L$. brevis $\mathrm{MBK} 34$ 단독 스타터보다 E. faecium KML12와의 혼합 스타터에 의해 균수가 낮게 나타난 것은 이들 균주들간의 영양 분에 대한 경합이나 항균 물질 생산에 의한 저해 작용에 따른 것으로 판단된다.

Lee 등[37]은 스타터를 첨가하지 않고 제조 직후 김치 유산 균수는 $9.42 \times 10^{4} \mathrm{CFU} / \mathrm{g}$ 이었고 시간이 경과함에 따라 증가되기 시작하여 4주 만에 $1.59 \times 10^{7} \mathrm{CFU} / \mathrm{g}$, 8주 만에 $5.01 \times 10^{9} \mathrm{CFU} /$ $\mathrm{g}, 12$ 주 만에 $1.65 \times 10^{8} \mathrm{CFU} / \mathrm{g}$ 으로 측정되어 8 주 만에 최대 균 수에 이르렀고 이후부터 균수는 서서히 감소되었다. 게다가 $L$. zymae GU20 세포 현탁액 $10^{7} \mathrm{CFU} / \mathrm{g}$ 을 접종한 제조 직후의 김치 내 유산균수는 $1.14 \times 10^{7} \mathrm{CFU} / \mathrm{g}$ 이었고 4주 만에 $4.21 \times 10^{7}$ $\mathrm{CFU} / \mathrm{g}, 8$ 주 만에 $4.67 \times 10^{9} \mathrm{CFU} / \mathrm{g}, 12$ 주 만에 $3.34 \times 10^{8} \mathrm{CFU} /$ $\mathrm{g}$ 으로 측정되어 스타터 무첨가구와 유사하게 저장 기간에 따른 균수 변화가 나타났다. 이러한 결과와 유사하게 본 연구에서도 대조구 및 스타터 첨가구의 초기 균수가 비슷한 수준이었고 발 효 기간에 따른 균수 변화도 유사하게 나타났다.

한편, Jung 등[38]은 담근 직후 김치의 산도는 $0.29-0.30 \%$ 이 었으나 7일 및 24일 후에는 각각 $0.32-0.36 \%$ 와 $0.36-0.40 \%$ 에 도달하였고 발효 기간에 따라 유의하게 산도가 증가되었다고 하 였다. 일반적으로 김치의 발효 과정 동안 $\mathrm{pH}$ 의 감소는 원료에 포함된 다양한 효소와 발효에 관여하는 미생물 사이의 상호 작 용에 의해 생산된 유기산 때문이다. 특히 김치의 산도와 $\mathrm{pH}$ 는 청량한 신맛을 제공하고 김치의 품질에 영향을 미치는 중요한
인자가 된다[39]. 김치 발효는 산도에 따라 초기(산도 $0.2 \%$ 이 하), 미숙(산도 $0.2-0.4 \%)$, 최적 숙성 $(0.4-0.9 \%)$ 및 과숙(산도 $0.9 \%$ 이상) 단계로 나눠진다. 산도는 유산균이 이용 가능한 당 의 발효를 통해 생성된 유산과 질산에 의하며 원료의 종류와 품질, 발효 조건 및 발효 미생물에 따라 산도에 차이가 있다 [27]. $4{ }^{\circ} \mathrm{C}$ 의 낮은 온도에 저장하면 발효 속도가 늦어지고 발효 기간이 길어진 반면 $10{ }^{\circ} \mathrm{C}$ 에서 저장한 김치는 초기 발효가 빠 르게 진행되어 최대 균수나 산도에 이른 후에는 일정한 수준을 유지하게 되므로 산도 변화는 발효 온도에 영향을 받는 것으로 알려져 있다[39].

\section{배추 김치 내 아미노산 함량에 대한 발효 스타터의 영향}

$\mathrm{BA}$ 생성균 단독 및 $\mathrm{BA}$ 분해균과의 혼합 스타터를 이용하여 제조한 김치를 $4{ }^{\circ} \mathrm{C}$ 및 $15^{\circ} \mathrm{C}$ 에서 발효시키는 동안 $\mathrm{BA}$ 생성을 위한 전구체 아미노산 함량 변화를 측정한 결과는 Table 5와 같다. 스타터를 첨가하지 않고 담근 직후의 김치 내 리신, 히스 티딘, 오르니틴 및 티로신의 함량은 각각 $30.5 \pm 3.4,15.5 \pm 1.1$, $45.2 \pm 3.1,25.6 \pm 0.9 \mathrm{mg} \%$ 로 측정되었다. $4{ }^{\circ} \mathrm{C}$ 에서 발효시킨 김치 에서는 발효가 진행됨에 따라 아미노산의 함량은 서서히 증가 되었으며 $15^{\circ} \mathrm{C}$ 에서도 리신과 오르니틴 함량은 서서히 증가된 반면 히스티딘과 티로신 함량은 60 일까지는 서서히 증가되다가 그 이후부터는 감소된 경향을 나타내었다. 발효가 진행될수록 김치 내 아미노산 함량은 $\mathrm{BA}$ 생성균 단독으로 사용했을 때 유 의하게 낮게 측정되었다 $(p<0.05)$. 카다베린 생성균인 $\mathrm{Leu}$. mesenteroides MBK32 단독 스타터를 이용한 경우 $4,15^{\circ} \mathrm{C}$ 에 서 90 일만에 각각 $26.4 \pm 5.0,23.8 \pm 1.7 \mathrm{mg} \%$ 이었으나, 카다베린 분해균인 L. fermentum MML21과 혼합 스타터로 이용한 경우 에는 동일한 조건에서 리신의 함량이 유의하게 높게 나타났다 $(p<0.05)$. 히스타민, 푸트레신 및 티라민 생성균 단독 스타터를 사용한 경우에도 $4{ }^{\circ} \mathrm{C}$ 에서는 히스티딘과 오르니틴 및 티로신의 함량이 서서히 증가되었으나 $15^{\circ} \mathrm{C}$ 에서 60 일 이후에는 증가량 이 크지 않았는데 이는 아미노산이 아민 생성에 이용되었기 때 문인 것으로 판단된다. 게다가 푸트레신 및 티라민 분해균과 혼 합 스타터로 이용된 경우에는 $4{ }^{\circ} \mathrm{C}$ 뿐만 아니라 $15^{\circ} \mathrm{C}$ 에서도 꾸 준히 증가되었는데 이는 분해균의 단백질 분해 효소 활성에 의 해 특정 아미노산의 생산량이 증가된 것으로 판단된다.

Lee와 Kim [40]은 김치 시료 내 유리 아미노산 함량은 초기 부터 7주간 저장하는 동안 유의미한 함량 변화를 나타내었고 시료에 따라 함량은 상이하다고 하였는데 이는 발효되는 동안 김치의 주재료와 부재료가 어우러지면서 아미노산 함량과 조성 에 영향을 주는 것으로 판단하였다. 또한 발효 기간이나 온도 등의 변화에 따라 아미노산의 함량에 차이가 크며, 아미노산은 김치의 풍미 제공 뿐만 아니라 발효 미생물의 증식에 중요한 영양원으로 이용되어 미생물의 단백질 분해 효소 활성에 의해 유리 아미노산 함량은 증가된다고 분석하였다. Oh와 Kim [41] 의 보고에 따르면 담근 직후의 김치 내 유리 아미노산 함량은 $319.55 \mathrm{mg} \%$ 이었으나 7일 후 $369.80 \mathrm{mg} \%, 21$ 일만에는 550 $\mathrm{mg} \%$ 로 증가되었다고 한 반면, $\mathrm{Nam}$ 등[42]은 총 아미노산 함 량은 초기에는 다소 증가되다가 발효 중반 이후부터는 점차적 으로 감소되었다고 보고된 바 있는데 본 연구의 결과에서는 스 타터 무첨가구인 대조구로부터 히스티딘과 티로신의 함량이 60 일 이후 감소된 경향을 나타낸 것은 $\mathrm{BA}$ 생성을 위한 전구체로 
Table 5 Effect of biogenic amine (BA)-forming and degrading starter cultures on changes of specific amino acid content in Baechu-kimchi prepared with Myeolchi-aekjeot during fermentation

\begin{tabular}{|c|c|c|c|c|c|c|c|c|}
\hline \multirow{3}{*}{ Starter } & \multicolumn{8}{|c|}{ Amino acid (mg\%) } \\
\hline & & \multirow{2}{*}{0} & \multicolumn{3}{|c|}{$4{ }^{\circ} \mathrm{C}$} & \multicolumn{3}{|c|}{$15^{\circ} \mathrm{C}$} \\
\hline & & & 30 days & 60 days & 90 days & 30 days & 60 days & 90 days \\
\hline None & & $30.5 \pm 3.4^{\mathrm{aA}}$ & $35.7 \pm 1.5^{\mathrm{bB}}$ & $40.3 \pm 0.2^{\mathrm{CC}}$ & $46.2 \pm 3.2^{\mathrm{dC}}$ & $38.9 \pm 6.1^{\mathrm{bcB}}$ & $45.3 \pm 0.4^{\mathrm{dC}}$ & $52.1 \pm 3.2^{\mathrm{eC}}$ \\
\hline Leuconostoc mesenteroides MBK32 & Lysine & $31.6 \pm 4.8^{\mathrm{cA}}$ & $30.2 \pm 0.6^{\mathrm{cA}}$ & $24.0 \pm 3.1^{\mathrm{aA}}$ & $26.4 \pm 5.0^{\mathrm{aA}}$ & $27.9 \pm 0.8^{\mathrm{bA}}$ & $24.3 \pm 1.8^{\mathrm{aA}}$ & $23.8 \pm 1.7^{\mathrm{aA}}$ \\
\hline Leuconostoc mesenteroides MBK32 Lactobacillus fermentum MML21 & & $29.2 \pm 3.2^{\mathrm{aA}}$ & $33.6 \pm 0.5^{\mathrm{bB}}$ & $35.0 \pm 2.3^{\mathrm{bB}}$ & $39.2 \pm 2.8^{\mathrm{bB}}$ & $36.1 \pm 1.4^{\mathrm{bB}}$ & $39.2 \pm 1.0^{\mathrm{cB}}$ & $42.1 \pm 2.5^{\mathrm{dB}}$ \\
\hline $\begin{array}{ll}\text { None } \\
\end{array}$ & & $15.5 \pm 1.1^{\mathrm{aA}}$ & $21.3 \pm 6.0^{\mathrm{bA}}$ & $26.2 \pm 4.6^{\mathrm{cB}}$ & $29.8 \pm 4.2^{\mathrm{dB}}$ & $22.5 \pm 2.3^{\mathrm{bBC}}$ & $37.8 \pm 3.0^{\mathrm{eC}}$ & $25.3 \pm 1.1^{\mathrm{cB}}$ \\
\hline Lactobacillus brevis MBK34 & Histidine & $16.8 \pm 2.0^{\mathrm{cA}}$ & $15.2 \pm 1.9^{\mathrm{cA}}$ & $13.7 \pm 4.4^{\mathrm{bA}}$ & $18.1 \pm 5.0^{\mathrm{cdA}}$ & $13.1 \pm 0.6^{\mathrm{bA}}$ & $11.0 \pm 0.9^{\mathrm{abA}}$ & $9.6 \pm 2.6^{\mathrm{aA}}$ \\
\hline Lactobacillus brevis MBK34 Enterococcus faecium KML12 & & $18.0 \pm 0.5^{\mathrm{aAB}}$ & $18.2 \pm 4.7^{\mathrm{aA}}$ & $23.6 \pm 1.9^{\mathrm{bB}}$ & $29.4 \pm 1.9^{\mathrm{cdB}}$ & $19.6 \pm 0.8^{\mathrm{aB}}$ & $25.1 \pm 3.4^{\mathrm{bcB}}$ & $23.4 \pm 0.5^{\mathrm{bB}}$ \\
\hline None & & $45.2 \pm 3.1^{\mathrm{aA}}$ & $52.1 \pm 3.0^{\mathrm{bB}}$ & $58.3 \pm 0.7^{\mathrm{CC}}$ & $66.3 \pm 1.7^{\mathrm{deC}}$ & $56.3 \pm 1.7^{\mathrm{bcC}}$ & $63.7 \pm 2.8^{\mathrm{dC}}$ & $70.2 \pm 1.4^{\mathrm{eC}}$ \\
\hline Lactobacillus curvatus MBK31 & Ornithine & $42.3 \pm 2.7^{\mathrm{cA}}$ & $38.5 \pm 4.8^{\mathrm{abA}}$ & $36.0 \pm 1.6^{\mathrm{aA}}$ & $38.7 \pm 0.5^{\mathrm{abA}}$ & $35.4 \pm 4.6^{\mathrm{aA}}$ & $43.1 \pm 0.9^{\mathrm{cA}}$ & $50.4 \pm 1.4^{\mathrm{dA}}$ \\
\hline Lactobacillus curvatus MBK31 $\quad$ Lactobacillus sakei MML23 & & $44.7 \pm 1.3^{\mathrm{bA}}$ & $37.8 \pm 2.2^{\mathrm{aA}}$ & $39.0 \pm 2.4^{\mathrm{aAB}}$ & $42.5 \pm 0.7^{\mathrm{abB}}$ & $41.1 \pm 4.9^{\mathrm{abB}}$ & $50.1 \pm 1.8^{\mathrm{cB}}$ & $64.7 \pm 9.8^{\mathrm{dB}}$ \\
\hline None & & $25.6 \pm 0.9^{\mathrm{aA}}$ & $29.0 \pm 0.4^{\mathrm{bAB}}$ & $34.7 \pm 8.0^{\mathrm{CC}}$ & $40.1 \pm 2.2^{\mathrm{deC}}$ & $33.5 \pm 4.8^{\mathrm{cB}}$ & $45.7 \pm 7.7^{\mathrm{eC}}$ & $38.1 \pm 0.3^{\mathrm{dC}}$ \\
\hline Enterococcus faecalis SBK31 & Tyrosine & $26.3 \pm 6.4^{\mathrm{cdA}}$ & $21.7 \pm 8.9^{\mathrm{bA}}$ & $20.6 \pm 4.6^{\mathrm{bA}}$ & $23.6 \pm 1.8^{\mathrm{cA}}$ & $16.9 \pm 3.6^{\mathrm{aA}}$ & $18.4 \pm 0.6^{\mathrm{abA}}$ & $20.4 \pm 2.5^{\mathrm{bA}}$ \\
\hline Enterococcus faecalis SBK31 Enterococcus faecium KML12 & & $24.9 \pm 0.8^{\mathrm{cA}}$ & $27.0 \pm 1.5^{\mathrm{dAB}}$ & $25.6 \pm 3.1^{\mathrm{cAB}}$ & $33.5 \pm 4.0^{\mathrm{eB}}$ & $18.9 \pm 3.7^{\mathrm{aA}}$ & $22.3 \pm 4.0^{\mathrm{abAB}}$ & $26.2 \pm 4.2^{\mathrm{cdB}}$ \\
\hline
\end{tabular}

All values are the mean $\pm \mathrm{SD}$ of the three replicates

${ }^{a-e}$ Values within a row with different superscripts are significantly each groups at $p<0.05$ by Duncan's multiple range test

${ }^{\mathrm{A}-\mathrm{C}}$ Values within a column with different superscripts are significantly each groups at $p<0.05$ by Duncan's multiple range test

Table 6 Effect of biogenic amine (BA)-forming and degrading starter cultures on changes of specific BA content in Baechu-kimchi prepared with Myeolchi-aekjeot during fermentation

\begin{tabular}{|c|c|c|c|c|c|c|c|c|}
\hline \multirow{3}{*}{ Starter } & \multicolumn{8}{|c|}{$\mathrm{BA}(\mathrm{mg} / \mathrm{kg})$} \\
\hline & & \multirow{2}{*}{0} & \multicolumn{3}{|c|}{$4{ }^{\circ} \mathrm{C}$} & \multicolumn{3}{|c|}{$15^{\circ} \mathrm{C}$} \\
\hline & & & 30 days & 60 days & 90 days & 30 days & 60 days & 90 days \\
\hline None & & ND & ND & ND & ND & ND & ND & ND \\
\hline Leuconostoc mesenteroides MBK32 & Cadaverine & $10.2 \pm 4.5^{\mathrm{aA}}$ & $25.7 \pm 3.9^{\mathrm{bA}}$ & $35.6 \pm 2.8^{\mathrm{cAB}}$ & $46.7 \pm 1.7^{\mathrm{dB}}$ & $34.1 \pm 6.8^{\mathrm{cB}}$ & $48.0 \pm 10.1^{\mathrm{dB}}$ & $68.7 \pm 9.5^{\mathrm{eB}}$ \\
\hline Leuconostoc mesenteroides MBK32 Lactobacillus fermentum MML21 & & $11.5 \pm 3.6^{\mathrm{aA}}$ & $22.3 \pm 1.3^{\mathrm{bA}}$ & $29.3 \pm 5.0^{\mathrm{cA}}$ & $36.1 \pm 4.2^{\mathrm{dA}}$ & $27.1 \pm 0.6^{\mathrm{cA}}$ & $34.5 \pm 5.2^{\mathrm{dA}}$ & $49.2 \pm 4.3^{\mathrm{eA}}$ \\
\hline \multirow{2}{*}{$\begin{array}{c}\text { None } \\
\text { Lactobacillus brevis MBK34 }\end{array}$} & & $13.7 \pm 2.4^{\mathrm{aA}}$ & $16.9 \pm 2.2^{\mathrm{abA}}$ & $17.5 \pm 0.5^{\mathrm{bA}}$ & $39.1 \pm 3.7^{\mathrm{eA}}$ & $22.4 \pm 1.2^{\mathrm{cA}}$ & $29.6 \pm 3.4^{\mathrm{dA}}$ & $38.2 \pm 3.0^{\mathrm{eA}}$ \\
\hline & Histamine & $15.4 \pm 6.1^{\mathrm{aA}}$ & $29.6 \pm 1.8^{\mathrm{bBC}}$ & $41.3 \pm 3.2^{\mathrm{cC}}$ & $50.3 \pm 2.9^{\mathrm{dB}}$ & $47.5 \pm 6.1^{\mathrm{dB}}$ & $66.5 \pm 12.5^{\mathrm{eC}}$ & $91.1 \pm 13.7^{\mathrm{fC}}$ \\
\hline Lactobacillus brevis MBK34 $\quad$ Enterococcus faecium KML12 & & $17.3 \pm 2.0^{\mathrm{aA}}$ & $22.8 \pm 5.6^{\mathrm{bB}}$ & $29.4 \pm 2.4^{\mathrm{cB}}$ & $38.2 \pm 1.3^{\mathrm{dA}}$ & $26.1 \pm 8.2^{\mathrm{bcA}}$ & $41.5 \pm 0.9^{\mathrm{deB}}$ & $56.8 \pm 2.6^{\mathrm{fB}}$ \\
\hline None & & ND & $\mathrm{ND}$ & ND & ND & ND & ND & $\mathrm{ND}$ \\
\hline Lactobacillus curvatus MBK31 & Putrescine & $13.4 \pm 0.8^{\mathrm{aA}}$ & $21.8 \pm 7.1^{\mathrm{bA}}$ & $31.2 \pm 1.9^{\mathrm{cA}}$ & $40.4 \pm 4.2^{\mathrm{eB}}$ & $20.8 \pm 4.4^{\mathrm{bA}}$ & $35.9 \pm 0.5^{\mathrm{dB}}$ & $52.7 \pm 1.9^{\mathrm{fB}}$ \\
\hline Lactobacillus curvatus MBK31 $\quad$ Lactobacillus sakei MML23 & & $12.9 \pm 5.7^{\mathrm{aA}}$ & $17.4 \pm 2.2^{\mathrm{bA}}$ & $27.1 \pm 4.7^{\mathrm{cA}}$ & $31.8 \pm 5.8^{\mathrm{dA}}$ & $16.4 \pm 2.2^{\mathrm{bA}}$ & $28.0 \pm 2.7^{\mathrm{cA}}$ & $39.1 \pm 1.6^{\mathrm{eA}}$ \\
\hline None & & $8.2 \pm 0.9^{\mathrm{aA}}$ & $12.4 \pm 1.7^{\mathrm{bA}}$ & $14.8 \pm 0.9^{\mathrm{cA}}$ & $19.2 \pm 2.0^{\mathrm{dA}}$ & $16.8 \pm 1.1^{\mathrm{cA}}$ & $20.0 \pm 0.8^{\mathrm{dA}}$ & $31.4 \pm 3.1^{\mathrm{eA}}$ \\
\hline Enterococcus faecalis SBK31 & Tyramine & $8.7 \pm 1.1^{\mathrm{aA}}$ & $20.4 \pm 5.5^{\mathrm{bB}}$ & $30.7 \pm 0.8^{\mathrm{dC}}$ & $37.3 \pm 2.6^{\mathrm{eC}}$ & $26.9 \pm 5.0^{\mathrm{bcB}}$ & $41.2 \pm 3.3^{\mathrm{efB}}$ & $50.5 \pm 8.2^{\mathrm{gC}}$ \\
\hline Enterococcus faecalis SBK31 Enterococcus faecium KML12 & & $8.0 \pm 1.3^{\mathrm{aA}}$ & $18.1 \pm 3.0^{\mathrm{bB}}$ & $22.8 \pm 1.2^{\mathrm{cB}}$ & $26.2 \pm 9.0^{\mathrm{cdAB}}$ & $23.6 \pm 2.8^{\mathrm{cB}}$ & $38.1 \pm 4.7^{\mathrm{efB}}$ & $40.1 \pm 6.8^{\mathrm{fB}}$ \\
\hline
\end{tabular}


이용되기 때문인 것으로 판단된다. Jung 등[28]은 발효 과정 중 아미노산 함량 감소는 유산균의 증식에 이용되었기 때문이라고 하였고 김치 내 젓갈의 역할은 아미노산 공급에 따른 풍미를 향상시키고 기능적 대사산물의 양을 증가시킨다고 보고하였다.

\section{배추 김치 내 $\mathrm{BA}$ 함량에 대한 발효 스타터의 영향}

$\mathrm{BA}$ 생성균 단독 및 $\mathrm{BA}$ 분해균과의 혼합 스타터를 이용하여 제조한 김치를 $4{ }^{\circ} \mathrm{C}$ 및 $15^{\circ} \mathrm{C}$ 에서 발효시키는 동안 $\mathrm{BA}$ 함량 변화를 측정한 결과는 Table 6과 같다. 스타터를 첨가하지 않 고 제조한 김치는 담근 직후부터 각각의 온도에서 90 일간 발효 시키는 동안 카다베린과 푸트레신을 검출되지 않았다. 하지만 담근 직후 히스타민과 티라민 함량은 각각 $13.7 \pm 2.4,8.2 \pm 0.9$ $\mathrm{mg} / \mathrm{kg}$ 으로 측정되었고 발효가 진행될수록 생성량은 점점 증가 되었으며 $4{ }^{\circ} \mathrm{C}$ 보다는 $15^{\circ} \mathrm{C}$ 에서 더 높게 나타났다. 발효가 진 행될수록 김치 내 $\mathrm{BA}$ 함량은 $\mathrm{BA}$ 생성균에 의해 유의하게 높 았고, $\mathrm{BA}$ 분해균과의 혼합 배양에 의해 유의하게 낮게 검출되 었다 $(p<0.05)$.

Leu. mesenteroides MBK32 단독 스타터로 담근 직후의 김치 에서 $10.2 \pm 4.5 \mathrm{mg} \%$ 의 카다베린이 검출되었고 높은 온도에서 발 효가 진행될수록 카다베린의 함량은 꾸준히 증가되었으나, $L$. fermentum MML21의 카다베린 분해능에 의해선 발효 기간 동 안 유의하게 낮은 양이 검출되었다. L. brevis MBK34 단독 스 타터로 담궈 $15^{\circ} \mathrm{C}$ 에서 90 일간 발효 시킨 김치에서 $91.1 \pm 13.7$ $\mathrm{mg} \%$ 의 히스타민이 검출되었으나, E. faecium KML12와 혼합 스타터를 이용한 경우에는 $56.8 \pm 2.6 \mathrm{mg} \%$ 로 유의하게 낮게 검 출되었다. L. curvatus $\mathrm{MBK} 31$ 단독 스타터를 사용한 경우보다 히스타민 분해균인 L. sakei MML23과의 혼합 스타터를 사용 한 김치에서 히스타민 함량이 유의하게 낮았으며 분해균에 의 한 $\mathrm{BA}$ 저감 효과는 E. faecalis SBK31과 E. faecium KML12 와의 혼합에 의해서도 나타났다.

젓갈이나 액젓은 발효되는 동안 효소와 풍미 성분을 제공하 는 중요한 부원료로서 단백질, 아미노산, 무기질을 함유하므로 김치의 영양학적 가치를 향상시키기도 하지만, 히스타민, 티라 민 및 베타-페닐에틸아민과 같은 유해한 $\mathrm{BA}$ 를 과량 함유하는 것으로 보고되고 있다[43,44]. 시판하는 액젓이나 젓갈의 $\mathrm{BA}$ 함 량은 발효 기간이 길어질수록 생성량이 증가되고 총 $\mathrm{BA}$ 양은 조단백질의 함량에 비례적으로 증가되며 김치의 $\mathrm{BA}$ 함량은 대 부분 액젓이나 젓갈로부터 기인하는 것으로 보고되고 있다[45]. 본 연구에 사용된 멸치 액젓 자체의 히스타민과 티라민 함량은 각각 $183.4 \pm 7.2 \mathrm{mg} / \mathrm{kg}$ 및 $10.7 \pm 2.8 \mathrm{mg} / \mathrm{kg}$ (결과 미 제시)으로 측정되었고, 이로 인하여 스타터를 첨가하지 않고 담근 직후의 김치에서 히스타민 $(13.7 \pm 2.4 \mathrm{mg} / \mathrm{kg})$ 과 티라민 $(8.2 \pm 0.9 \mathrm{mg} / \mathrm{kg})$ 이 검출되었으며 발효가 진행됨에 따라 원료 내 아미노산의 탈탄 산화를 통해 $\mathrm{BA}$ 생성량이 증가된 것으로 보인다. Mah 등[46] 에 따르면 까나리 액젓과 육젓의 히스타민 $(959.7 \mathrm{mg} / \mathrm{kg})$ 을 제외 한 $\mathrm{BA}$ 함량은 $250 \mathrm{mg} / \mathrm{kg}$ 이하로 비교적 낮은 양이 검출된 반 면 이들에 비해 멸치 액젓은 상당히 많은 양의 $\mathrm{BA}$ 가 검출되었 고 특히 가장 많은 양의 히스타민(최대 $1154.7 \mathrm{mg} / \mathrm{kg}$ )이 검출되 었다. 멸치 액젓의 히스타민 함량은 높은 온도에서 저장하는 동 안 급증하여 중독을 유발할 정도의 양(약 $1000 \mathrm{mg} / \mathrm{kg}$ )에 이른 다고 보고하였다. 하지만 적당한 조건에서 숙성 및 저장된 멸 치 액젓 시료 내 BA 함량(푸트레신 $86.1 \mathrm{mg} / \mathrm{kg}$, 티라민 222.6 $\mathrm{mg} / \mathrm{kg}$, 히스타민 $690.9 \mathrm{mg} / \mathrm{kg}$ )이 건강을 위협할 정도는 아니므 로 김치 섭취로 인한 $\mathrm{BA}$ 중독 가능성은 높지 않다고 고찰하 였다.

한편, 배추 김치 내 트립타민, 푸트레신, 카다베린, 히스타민 및 티라민 함량 감소는 Leu. carnosum, Leu. mesenteroides, L. plantarum 및 L. sakei 등의 $\mathrm{BA}$ 생성능이 없는 발효 스타터의 이용에 의해 나타난 것으로 보고되었다[47]. Kalac 등[48]은 사 우어크라우트 제조 시 L. plantarum, Lactobacillus casei, P. pentosaceus, E. faecium 등의 스타터를 접종하여 발효시킨 경 우 자연 발효된 시료보다 유의하게 낮은 $\mathrm{BA}$ 가 검출되었다고 보고한 바 있어 아미노산 탈탄산 효소를 생산하지 않는 스타터 의 활용은 $\mathrm{BA}$ 중독 위험을 감소시키는데 유용할 것으로 판단 된다. $\mathrm{BA}$ 독성물질을 무독화시킬 수 있는 아민 산화효소(amino oxidase) 활성이 Lactobacillus sp., Pediococcus sp., Oenococcus $\mathrm{sp}$. 등의 유산균으로부터 확인되었고, 히스타민과 티라민 분해 능이 있는 L. casei를 Cabrales 치즈 제조에 이용한 결과 유해 아민 축적량이 유의하게 감소된 것으로 밝혀져[49], BA 분해능 을 나타내는 균주를 발효 식품의 제조에 이용하는 것이 $\mathrm{BA}$ 저 감화에 효과적이라고 보고된 바 있다. 특정 세균의 $\mathrm{BA}$ 분해능 은 아민 산화효소 혹은 다중 구리 산화효소(multi copper oxidase) 활성에 기인하는 것으로 보고된 바 있다[50]. 본 연구 에서도 $\mathrm{BA}$ 생성균과 분해균 혼용 시 $\mathrm{BA}$ 함량은 자연 발효로 부터 측정된 양 만큼의 수준에 미치지는 못했지만, $\mathrm{BA}$ 생성균 단독에 비해 $\mathrm{BA}$ 함량이 다소 감소된 결과가 나타났다. 따라서 김치 발효 과정 중 외부로부터 $\mathrm{BA}$ 생성균이 혼입될 경우 $\mathrm{BA}$ 생성을 억제시키기 위해서는 $\mathrm{BA}$ 분해능이 있는 스타터를 활용 하는 것이 효과적일 것으로 판단된다. Moon 등[51]은 박테리오 신을 생산하는 Enterococcus sp.을 김치 제조용 스타터로 활용 한 경우 저장 기간을 연장시키는데 효과적이라고 하였고, $\mathrm{Kim}$ 등[52]은 묵은지로부터 분리된 L. sakei JK-17은 항산화 및 항 균 활성을 나타내었다고 보고한 바 있다. 본 연구의 $L$. fermentum MML21, E. faecium KML12 및 L. sakei MML23 은 $\mathrm{BA}$ 분해 활성이 있으므로 김치 발효 스타터로 이용할 경우 $\mathrm{BA}$ 로 인한 독성 위험을 낮추는데 효과적일 것이다.

Casquete 등[53]에 따르면 Pediococcus acidilactici MS200, P. acidilactici MS198 및 Staphylococcus vitulus RS34와의 혼 합 배양 했을 때 발효 온도가 높을수록 BA 생성량 감소 효과 가 크게 나타났고 이는 발효 환경에 대한 스타터의 적응력이 좋았기 때문이라고 고찰하였다. 본 연구에서도 $4{ }^{\circ} \mathrm{C}$ 보다는 $15^{\circ} \mathrm{C}$ 에서 아미노산 탈탄산 효소 활성이 강해 $\mathrm{BA}$ 감소 효과가 더 크게 나타난 것으로 판단된다. 식품 과학과 산업 분야에서 고압 처리나 저선량 방사선 조사가 $\mathrm{BA}$ 함량을 감소시키는 것 으로 보고된 바 있으나[54], 이러한 물리적인 방법은 식품 물성 변화 및 안전성에 문제가 될 수도 있기 때문에 $\mathrm{BA}$ 분해능이 있는 스타터를 활용하는 것이 좋은 대안이 될 수 있을 것이다. $\mathrm{BA}$ 는 비위생적인 취급 과정 중에 다량 생성 되어 식품의 품질 을 판단하는 지표 물질로서 원료나 외부 환경으로부터 특이한 탈탄산 효소 활성을 나타내는 야생형 미생물의 오염을 막기 위 해 발효 조건 개선과 위생적인 환경 하에서 식품을 제조하고 $\mathrm{BA}$ 함량이 낮은 원료를 사용함으로써 $\mathrm{BA}$ 생성을 효과적으로 억제시킬 수 있을 것이다. 김치와 같은 발효 채소류로부터 다 양한 $\mathrm{BA}$ 가 검출되고 일부 시료에서는 섭취 허용 한계치인 100 
$\mathrm{mg} / \mathrm{kg}$ 을 초과하기도 하므로 발효 및 저장 기간 동안 이들 유 해물질 함량의 꾸준한 모니터링과 $\mathrm{BA}$ 에 의한 중독 예방을 위 한 다양한 제어 방법 모색이 필요하다. 아미노산 탈탄산 효소 분해능이 있는 유산균을 발효 스타터로 이용하게 되면 BA 생 성량을 낮춰 안전한 발효 식품 제조가 가능할 것으로 판단된 다. 균주에 따라 $\mathrm{BA}$ 분해능에 차이가 있으므로 분해 활성이 강 한 스타터 균주의 분리 탐색과 발효 환경에 따라 균주의 효소 활성이 다를 수 있으므로 BA 함량을 최대한으로 낮출 수 있는 최적의 발효 조건 설정에 관한 연구가 추후에 필요할 것이다.

\section{초 록}

본 연구의 목적은 발효 기간 동안 멸치 액젓과 새우젓으로 담 근 배추 김치로부터 분리 동정된 바이오제닉 아민(biogenic amines, BA) 생성 유산균 단독 스타터 혹은 BA 분해 유산균 과의 혼합 스타터로 제조한 김치의 품질 특성을 조사하고자 하 였다. 발효가 진행될수록 새우젓 보다 멸치 액젓을 첨가하여 제 조한 김치에서 유산균수, 산도 및 $\mathrm{BA}$ 함량이 높게 나타났다. 유산균이 생산하는 $\mathrm{BA}$ 의 종류 및 생성량은 균종 보다는 균주 에 의존적이었다. 분리 균주 중에서 가장 많은 양의 카다베린, 히스타민, 푸트레신 및 티라민은 각각 Leuconostoc mesenteroides MBK32, Lactobacillus brevis MBK34, Lactobacillus curvatus $\mathrm{MBK} 31$ 및 Enterococcus faecalis SBK31로부터 생산되었다. $\mathrm{BA}$ 생성능과 분해능이 있는 스타터는 김치 내 유산균의 증식 속도와 산 생성능에 중요한 역할을 하였다. BA 생성균 단독 스 타터에 의해 증가된 김치의 $\mathrm{BA}$ 함량은 $\mathrm{BA}$ 분해균과의 혼합 스타터에 의해 효과적으로 감소되었다.

Keywords 김치 · 바이오제닉 아민 · 유산균

\section{References}

1. Food and Agricultural Organisation (FAO) (1998) Fermented fruits and vegetables: A global perspective. In Mike Battock et al. (eds.), FAO of United Nations, Rome, Italy

2. Steinkraus KH (2002) Fermentations in World Food Processing. Comp Rev Food Sci Food Safety 1: 23-32

3. Cooke RD, Twiddy DR, Reilly PJA (1987) Lactic acid fermentation as a low cost means of food preservation in tropical countries. FEMS Microbiol Rev 46: 369-379

4. Altay F, Karbancýoglu-G€uler F, Daskaya-Dikmen C, Heperkan D (2013) A review on traditional Turkish fermented non-alcoholic beverages: microbiota, fermentation process and quality characteristics. Int J Food Microbiol 167: 44-56

5. Tamang JP, Kailasapathy K (2010) Fermented foods and beverages of the world, pp. 149-160. CRC press. Taylor \& Francis Group. New York, USA

6. Nout MJR (1994) Fermented foods and food safety. Food Res Int 27: 291-298

7. Halász A, Baráth Á, Simon-Sarkadi L, Holzapfel W (1994) Biogenic amines and their production by microorganisms in food. Trends Food Sci Technol 5: 42-49

8. Stratton JE, Hutkins RW, Taylor SL (1991) Biogenic amines in cheese and other fermented foods: A review. J. Food Prot 54: 460-470

9. Mah JH, Park YK, Jin YH, Lee JH, Hwang HJ (2019) Bacterial production and control of biogenic amines in Asian fermented soybean foods. Foods 8: 85-99

10. Spano G, Russo P, Lonvaud-Funel A, Lucas P, Alexandre H, Grandvalet C, Coton E, Coton M, Barnavon L, Bach B, Rattray F, Bunte A, Magni C, Ladero V, Alvarez M, Fernández M, Lopez P, De Palencia PF, Corbi A, Trip H, Lolkema JS (2010) Biogenic amines in fermented foods. Eur J Clin Anutr 64: S95-S100

11. Sanlier N, Gökcen BB, Sezgin AC (2017) Health benefits of fermented foods. Crit Rev Food Sci Nutr 59: 506-527

12. Park YK, Lee JH, Mah JH (2019) Occurrence and reduction of biogenic amines in kimchi and Korean fermented seafood products. Foods 8: 547-561

13. Kalaè P, Špièka J, Køižek M, Steidlová Š, Pelikánová T (1999) Concentrations of seven biogenic amines in sauerkraut. Food Chem 67: 275-280

14. Barbieri F, Montanari C, Gardini F, Tabanelli G (2019) Biogenic amine production by lactic acid bacteria: A review. Foods 8: 17-43

15. Niu T, Li X, Guo Y, Ma Y (2019) Identification of a lactic acid bacteria to degrade biogenic amines in Chinese rice wine and its enzymatic mechanisms. Foods 8: 312-325

16. Lim ES (2020) Evaluation of microbial contamination levels and biogenic amines content in over-ripened kimchi. Korean Soc Food Pres 27: 635-650

17. Toy N, Özogul F, Özogul Y (2015) The influence of the cell free solution of lactic acid bacteria on tyramine production by food borne-pathogens in tyrosine decarboxylase broth. Food Chem 173: 45-53

18. Lim ES (2016) Effect of the mixed culture of heterfermentative lactic acid bacteria and acid-tolerant yeast on the shelf-life of sourdough. Korean J Microbiol 52: 471-481

19. Han GH, Cho TY, Yoo MS, Kim CS, Kim JM, Kim HA, Kim MO, Kim SC, Lee SA, Ko YS (2007) Biogenic amines formation and content in fermented soybean paste (Cheonggukjang). Korean J Food Sci Technol 39: $541-545$

20. Lee YK, Lee MY, Kim SD (2004) Effect of monosodium glutamate and temperateure change on the content of free amino acids in kimchi. J Korean Soc Food Sci Nutr 33: 399-404

21. Lee GI, Lee HM, Lee CH (2012) Food safety issues in industrialization of traditional Korean foods. Food Control 24: 1-5

22. Park JM, Shin JH, Lee DW, Song JC, Suh HJ, Chang UJ, Kim JM (2010) Identification of the lactic acid bacteria in kimchi according to initial and over-ripened fermentation using PCR and 16S rRNA gene sequence analysis. Food Sci Biotechnol 19: 541-546

23. Mheen TI, Kwon TW (1984) Effect of temperature and salt concentration on kimchi fermentation. Korean J Food Sci Technol 16: $443-450$

24. Jung JY, Lee SH, Lee HJ, Seo HY, Park WS, Jeon CO (2012) Effects of Leuconostoc mesenteroides starter cultures on microbial communities and metabolites during kimchi fermentation. Int J Food Microbiol 153: 378-387

25. Hong SW, Choi YJ, Lee HW, Yang JH, Lee MA (2016) Microbial community structure of Korean cabbage kimchi and ingredients with denaturing gradient gel electrophoresis. J Microbiol Biotechnol 26: $1057-1062$

26. Cheigh HS, Park KY (1994) Biochemical, microbiological, and nutritional aspects of kimchi. Crit Rev Food Sci Nutr 34: 175-203

27. Patra JK, Das G, Paramithiotis S, Shin HS (2016) Kimchi and other widely consumed traditional fermented foods of Korea: a review. Front Microbiol 7: 1493-1507

28. Jung MY, Kim TW, Lee CS, Kim JY, Song HS, Kim YB, Ahn SW, Kim JS, Roh SW, Lee SH (2018) Role of jeotgal, a Korean traditional fermented fish sauce, in microbial dynamics and metabolite profiles during kimchi fermentation. Korean Soc Food Sci Nutr 10: 370

29. Choi HJ, Lee NK, Paik HD (2015) Health benefits of lactic acid bacteria isolated from kimchi, with respect to immunomodulatory effects. Food Sci Biotechnol 24: 783-789 
30. Kwak SH, Cho YM, Noh GM, Om AS (2014) Cancer preventive potential of kimchi lactic acid bacteria (Weissella cibaria, Lactobacillus plantarum). J Cancer Prev 19: 253-258

31. Özogul F, Hamed I (2018) The importance of lactic acid bacteria for the prevention of bacterial growth and their biogenic amines formation: A review. Crit Rev Food Sci Nutr 58: 1660-1670

32. Tsai YH, Kung HF, Lin QL, Hwang JH, Cheng SH, Wei CI, Hwang DF (2005) Occurrence of histamine and histamine-forming bacteria in kimchi products in Taiwan. Food Chem 90: 635-641

33. Kim MJ, Kim KS (2014) Tyramine production among lactic acid bacteria and other species isolated from kimchi. LWT-Food Sci Technol 56: $406-413$

34. Jeong DW, Lee JH (2015) Antibiotic resistance, hemolysis and biogenic amine production assessments of Leuconostoc and Weissella isolates for kimchi starter development. LWT-Food Sci Technol 64: 1078-1084

35. Sgarbi E, Bottari B, Gatti M, Neviani E (2014) Investigation of the ability of dairy nonstarter lactic acid bacteria to grow using cell lysates of other lactic acid bacteria as the exclusive source of nutrients. Int J Dairy Technol 67: 342-347

36. Connil N, Plissoneau L, Onno B, Pilet MF, Prevost H, Dousset X (2002) Growth of Carnobacterium divergens V41 and production of biogenic amines and divercin V41 in sterile cold-smoked salmon extract at varying temperatures, $\mathrm{NaCl}$ levels, and glucose concentrations. J Food Prot 65: 333-338

37. Lee KW, Shim JM, Yao Z, Kim JA, Kim JH (2018) Properties of kimchi fermented with GABA-producing lactic acid bacteria as a starter. J Microbiol Biotechnol 28: 534-541

38. Jung SJ, Kim MJ, Chae SW (2016) Quality and functional characteristics of kimchi made with organically cultivated young Chinese cabbage (olgari-baechu). J Ethn Foods 3: 150-158

39. You SY, Yang JS, Kim SH, Hwang IM (2017) Changes in the physicochemical quality characteristics of cabbage kimchi with respect to storage conditions. J Food Qual 2017: 1-7

40. Lee HH, Kim GH (2013) Changes in the levels of $\gamma$-aminobutyric acid and free amino acids during kimchi fermentation. Korean J Food Cookery Sci 29: 671-677

41. Oh YE, Kim SD (1997) Changes in enzyme activities of salted Chinese cabbage and kimchi during salting and fermentation. J Korean Soc Food Sci Nutr 26: 404-410

42. Nam HG, Jang MS, Seo KC, Nam KH, Park HY (2013) Changes in the taste compounds of kimchi with seafood added during its fermentation. J Food Preserv 20: 404-418

43. Joung BC, Min JG (2018) Changes in post-fermentation quality during the distribution process of anchovy (Engraulis japonicus) fish sauce. J Food Prot 81: 969-976

44. Shin SW, Kim YS, Kim YH, Kim HT, Eum KS, Hong SR, Kang HJ, Park KH, Yoon MH (2019) Biogenic-amine contents of Korean commercial salted fishes and cabbage kimchi. Korean J Fish Aquat Sci 52: $13-18$

45. Cho TY, Han GH, Bahn KN, Son YW, Jang MR, Lee CH, Kim SH, Kim DB, Kim SB (2006) Evaluation of biogenic amines in Korean commercial fermented foods. Korean J Food Sci Technol 38: 730-737

46. Mah JH, Kim YJ, No HK, Hwang HJ (2004) Determination of biogenic amines in kimchi, Korean traditional fermented vegetable products. Food Sci Biotechnol 13: 826-829

47. Kim SH, Kang KH, Lee S, Kim SJ, Kim JG, Chung MJ (2017) Kimchi probiotic bacteria contribute to reduced amounts of N-nitrosodimethylamine in lactic acid bacteria-fortified kimchi. LWT-Food Sci Technol 84: 196203

48. Kalaè P, Špièka J, Køižek M, Steidlová Š, Pelikánová T (2000) The effects of lactic acid bacteria inoculants on biogenic amines formation in sauerkraut. Food Chem. 70: 355-359

49. Herrero-Fresno A, Martinez N, Sanchez-Llana E, Diaz M (2012) Lactobacillus casei strains isolated from cheese reduce biogenic amine accumulation in an experimental mode. Int J Food Microbiol 157: 297 304

50. Ladero V, Herrerofresno A, Martinez N, Rio BD, Linares DM, Fernández M (2014) Genome sequences analysis of the biogenic aminedegrading strain Lactobacillus casei 5b. Genome Announcements 2: e1199-121

51. Moon GS, Kang CH, Pyun YR, Kim WJ (2004) Isolation, identification, and characterization of a bacteriocin-producing Enterococcus sp. from kimchi and its application to kimchi fermention. J Microbiol Biotechnol 14: 924-931

52. Kim DS, Cho HW, Kim DH, Oh KH (2013) Functional characterization of Lactobacillus sakei JK-17 isolated from long-term fermented kimchi, Muk Eun Ji. Kor Soc Biotechnol Bioeng 28: 18-23

53. Casquete R, Benito MJ, Martín A, Ruiz-Moyano S, Hernández A, Córdoba MG (2011) Effect of autochthonous starter cultures in the production of "salchichón", a traditional Iberian dry-fermented sausage, with different ripening processes. Food Sci Technol 44: 1562-1571

54. Alvarez MA, Moreno-Arribas MV (2014) The problem of biogenic amines in fermented foods and the use of potential biogenic aminedegrading microorganisms as a solution. Trend Food Sci Technol 39: 146-155 